\title{
External Shocks in a Small Open Economy: A CGE - Microsimulation Analysis
}

\author{
Vaqar Ahmed" and Cathal O’Donoghue
}

\begin{abstract}
This paper studies the impact of changes in the external balance of Pakistan. We explain why the economic growth achieved during the past decade was highly dependent on improvements in the external balance. Between 2001 and 2007, Pakistan benefited from an increase in remittances, foreign assistance from bilateral and multilateral sources, and a relatively stable exchange rate. After 2007, this performance came under pressure from external price shocks. The rise in the import prices of petroleum, raw materials and other manufactured goods has the potential to reduce the country's growth performance, impacting the competitiveness of the economy and threatening the gains achieved during past years. We integrate a computable general equilibrium (CGE) model with a microsimulation model to study the effects of changes in foreign savings and import prices faced by Pakistan. An increase in foreign savings leads to an increase in imports and a decrease in exports. The main sectors facing a decline in exports are textiles, leather, cement, and livestock. In this simulation food and oil prices decline and the factors of production that gain are agricultural wage labor and nonagricultural unskilled wage labor. The increase in import prices of petroleum or industrial raw material leads to a reduction in exports. In this simulation the crop sector is negatively impacted and returns to land and profits to farm owners increase, showing a change in favor of agricultural asset owners, while poverty and inequality increase.
\end{abstract}

Keywords: Microsimulation, computable general equilibrium, poverty, inequality, balance of payments, Pakistan.

JEL Classification: D58, C81, C82, H22, D58, C51, I32.

\footnotetext{
* Macroeconomics Section, Planning Commission, Islamabad.

** Head, Rural Economy Research Centre, Teagasc, Athenry, Ireland.
} 


\section{Introduction}

The external account impacts economic growth through aid, trade, and foreign investment. The major issues affecting Pakistani balance of payments are the expensive structure of foreign savings and terms of trade shocks. Foreign savings are known to play an important role in the infrastructure and social sector needs of developing countries (see Husain 2007). There are two forms of foreign savings: debt and nondebt. The nondebt sources of foreign savings are usually less of a concern if compared with short- and medium-term debt instruments. According to conventional economic thinking, developing economies should not rely solely on national savings, but should put in place mechanisms to bring in foreign direct and portfolio investment (see Reisen and Soto 2001).

Short-term debt under weak macroeconomic fundamentals is expensive and has been responsible in the past for plunging several developing countries into a debt trap (see Voyvoda and Yeldan 2005). A persistent current account deficit also puts adverse pressure on national budgetary targets, bringing about the phenomenon commonly known as 'twin deficits' (see Aristovnik 2008).

The general equilibrium dynamics of aid and grants are explained in Anderson et al. (2003), who bifurcate the effects of aid into (a) the diversion of resources, and (b) real currency appreciation. Project-based aid diverts resources away from ongoing and existing production activities. Even where projects are funded entirely by foreign capital, human capital is taken away from existing activities. Most development projects are publically administered, and this implies that resources may be inefficiently allocated as the private sector now faces increased costs of production due to increases in labor wages and the price of raw materials. This effect seems plausible and can be observed in several developing economies.

The inflow of foreign capital can cause the exchange rate to appreciate, which in turn increases real wages and imports. This has implications for exports and future economic growth. Recent literature shows that several Asian economies have defended their (competitive) exchange rates in order to promote growth. This debate is highlighted in Bresser-Pereira and Gala (2008).

In the wake of trade liberalization, the import volumes of developing countries have generally increased. There is evidence that after liberalization, there has been an increase in economic growth at the cost of a rising trade deficit (see Pacheco-López and Thirlwall, 2007). The manner in which import prices impact local prices has been studied in the literature 
using primarily two methodologies, (a) the pass-through approach, and (b) the Armington elasticity approach. Studies focusing on the pass-through of exchange rates and import prices to domestic inflation reveal that import price shocks have a much larger impact on domestic inflation in comparison to exchange rate shocks (see McCarthy 2007). An accommodative monetary policy combined with exchange rate changes may however trigger the inflation-depreciation spiral (see Ito and Sato 2008). The Armington approach is commonly used in CGE models where the elasticity of substitution is assumed for the import and domestic production of a good. This paper also uses this approach. See Warr (2005) for the relationship between the pass-through and Armington approach.

Studies focusing on the rise in international oil prices find a reduction in welfare and economic growth (see Zaouali, 2007 and Schintke, et a1. 2000). In a general equilibrium framework, energy prices faced by households and producers can have varying distributional impacts. Countries that have a deregulated energy sector through price reforms provide interesting insights. In Indonesia's case, Yusuf and Resosudarmo (2008) show how differentiated prices for domestic and commercial fuel can make the overall reform process (deregulation) progressive. Several countries including Pakistan have tried until recently not to pass on the impact of rising energy prices by subsidizing the overall price (see Baclajanschi, et al. 2007).

During the 1990s, Pakistan struggled with its debt servicing due to the misappropriation of funds, poor fiscal efforts, and a continuously depreciating exchange rate. The recovery from the twin deficits after 2001 allowed Pakistan to retire its expensive short-term debt, and until 2007 it only had medium- to long-term debt commitments under multilateral and bilateral arrangements. Like any other low- and middle-income country, Pakistan is a price-taker and its current account is exposed to shocks in global export and import prices. This issue is of critical importance because of the lack of diversification in the overall export structure of Pakistan. The structure of imports also plays an important role in sustaining the long-run development of a country. What is important is that a country imports more capital goods than consumption goods. Due to the growth in large-scale manufacturing (seen during this decade) the import of machinery and other inputs has increased to unprecedented levels. However oil price shocks have remained a continuous threat to the overall terms of trade. More recently, local food shortages have led Pakistan to importing food (mainly wheat) at high rates.

Our reason for studying these external account changes in a CGE framework is motivated by the literature on trade reforms in particular and global economic liberalization in general. A CGE model is an economy-wide 
framework that shows how a specific change in the economy impacts other sectors, markets, or institutions. These models are widely used for analysis pertaining to taxation, trade liberalization, environment, natural resource policy, and regional development. The data used for the construction of CGE models is commonly known as a social accounting matrix (SAM). Examples of CGE models developed for Pakistan include McCarthy and Taylor (1980), Labus (1988), Vos (1998), Naqvi (1998), Siddiqui and Kemal (2002), Ahmed and O’Donoghue (2010).

Since the seminal work by Orcutt (1957), micro-simulation models have been widely used to study the micro-level impacts of socioeconomic policies. These models use household budget data and allow the explicit incorporation of $\operatorname{tax}$ and benefit-related rules and regulations. Microsimulation models are made behavioral through the incorporation of an expenditure system, and wage and occupational choice functions.

The integration of CGE models with microsimulation models has allowed us to obtain the micro-impacts of macroeconomic changes by making use of heterogeneity in household-level surveys (see Davies 2004). Gunter, Cohen and Lofgren (2005) present a review on analyzing macro-poverty linkages (see also Robinson and Lofgren 2005, Kraev and Akolgo 2005). Ben Hammouda and Osakwe (2008) look at the trade-focused CGE models in Africa. Cockburn, et al. (2008) summarize general equilibrium lessons on the trade-poverty nexus in African and Asian countries.

In this paper we look at the welfare impact of changes in foreign savings and world import prices. For the latter, we are particularly interested in the import price of petroleum and industrial raw material. The next section describes recent trends in Pakistan's socioeconomy with special reference to the external balance during the high growth period from 2001 to 2007. Section 3 will describe our model framework, data, parameterization, related measurement issues, and the design of simulations. Section 4 explains the impact of changes in foreign savings and Section 5 explains the import price effects. Section 6 then concludes the article and provides a summary of our main findings.

\section{Growth, Trade, and Welfare in Pakistan}

Since 1960, Pakistan's economy has grown at an average rate of 5.6 percent. The 1960s exhibited the highest annual average growth rate of 6.8 percent derived from an increase in manufacturing $(9.9$ percent $)$ and agriculture $(5.1$ percent). During this period, Pakistan received substantial aid from bilateral and multilateral development partners. Public sector 
expenditure was focused on public works and the setting up of necessary infrastructure for future growth requirements.

Table-1 Growth, Trade, and Welfare: Historic Overview

\begin{tabular}{|c|c|c|c|c|c|}
\hline & 1960s & 1970s & 1980s & $1990 s$ & 2000-07 \\
\hline & \multicolumn{5}{|c|}{ Annual Average } \\
\hline & \multicolumn{5}{|c|}{ Real Growth Rates (\%) } \\
\hline GDP & 6.8 & 4.8 & 6.5 & 4.6 & 5.4 \\
\hline Agriculture & 5.1 & 2.4 & 5.4 & 4.4 & 3.4 \\
\hline Manufacturing & 9.9 & 5.5 & 8.2 & 4.8 & 8.6 \\
\hline Commodity Producing Sector & 6.8 & 3.9 & 6.5 & 4.6 & 4.9 \\
\hline \multirow[t]{2}{*}{ Services Sector } & 6.7 & 6.3 & 6.7 & 4.6 & 5.8 \\
\hline & \multicolumn{5}{|c|}{ As \% of GDP } \\
\hline Total Investment & - & 17.1 & 18.7 & 18.3 & 18.6 \\
\hline Fixed Investment & - & 15.9 & 17.0 & 16.6 & 17.1 \\
\hline Public Investment & - & 10.3 & 9.2 & 7.5 & 4.8 \\
\hline Private Investment & - & 5.6 & 7.8 & 9.1 & 12.3 \\
\hline National Savings & - & 11.2 & 14.8 & 13.8 & 17.9 \\
\hline Foreign Savings & - & 5.8 & 3.9 & 4.5 & 0.8 \\
\hline Domestic Savings & - & 7.4 & 7.7 & 14.0 & 16.8 \\
\hline Total Revenue & 13.1 & 16.8 & 17.3 & 17.1 & 14.1 \\
\hline Tax Revenue & - & - & 13.8 & 13.4 & 10.7 \\
\hline Total Expenditure & 11.6 & 21.5 & 24.9 & 24.1 & 18.1 \\
\hline Current Expenditure & - & - & 17.6 & 19.4 & 14.9 \\
\hline Development Expenditure & - & - & 7.3 & 4.7 & 3.3 \\
\hline Overall Deficit & 2.1 & 5.3 & 7.1 & 6.9 & 4.0 \\
\hline Exports (fob) & - & - & 9.8 & 13.0 & 12.5 \\
\hline Imports (fob) & - & - & 18.7 & 17.4 & 15.4 \\
\hline \multirow[t]{2}{*}{ Trade Deficit } & - & - & 8.9 & 4.4 & 2.9 \\
\hline & \multicolumn{5}{|c|}{ Annual Average } \\
\hline Gini Coefficient* & 0.39 & 0.38 & 0.37 & 0.39 & 0.34 \\
\hline Poverty Headcount** & 42.4 & 38.6 & 20.9 & 27.3 & 26.9 \\
\hline Unemployed \%*** & - & 2.2 & 3.5 & 5.6 & 7.1 \\
\hline
\end{tabular}

Source: Economic Survey of Pakistan 2007-08. Some figures for 1960s and 1970s are missing on account of the separation of East Pakistan (now Bangladesh).

* Gini estimates from Anwar 2005, For 2005-07 estimates from the Economic Survey.

**Until 1999 from Haq \& Bhatti 2001. After that from Economic Survey 2007-08.

***Labour Force Survey. 
However Table-1 indicates that this impressive growth performance could not be sustained in the longer term. During the 1970s, the government tried to implement a model of nationalization that aimed at bringing productive resources (in identified sectors) under the control of the government. This resulted in a mismanaged endeavor where most established entrepreneurs left the country along with their moveable assets. The average growth rate during the decade fell to 4.8 percent; the agriculture and manufacturing growth rate fell to 2.4 percent and 5.5 percent, respectively. The nationalization experience however kept the unemployment level below 3 percent during the 1970s. To some extent, this resulted in a marginal decline in inequality. The poverty headcount ratio declined from an average of 42.4 percent in the 1960 s to 38.6 percent during the 1970s, showing a decline of almost 9 percent. During the 1970s, the total investment-to-GDP ratio fell to its lowest, averaging around 17 percent. The public investment-to-GDP ratio stood at 10.3 percent while the private investment-to-GDP ratio was 5.6 percent. The savings requirement for the economy was augmented largely through a current account deficit that averaged 5.8 percent of GDP during the decade.

During the 1978-1988 period, there was a partial move to restore the elements of private property and the free market, but the operational control of the government existed largely through a detailed licensing framework. The real GDP growth rate during the 1980 s averaged around 6.5 percent with agriculture and manufacturing growing at 5.4 and 8.2 percent, respectively. Both total investment and national savings as a ratio to GDP showed reasonable improvement, with an average of 18.7 and 14.8, percent respectively. The 1980s posed challenges for Pakistan in the wake of a record influx of Afghan refugees into Pakistan. The new geographical challenges substantially increased government expenditure on defense, public administration, and related activities. Ultimately, the increased budgetary expenditure resulted in an increase in the average fiscal deficit from 2.1 percent during the 1960 s to 7.1 percent during the 1980s. There was added pressure in the form of a high trade deficit of around 9 percent of GDP. This was attributed to the rise in imports (18.7 percent of GDP) and low levels of exports (9.8 percent of GDP).

The post-1988 period, was marked by frequent changes in operational strategy, which in most instances resulted in economic policy reversals. However, the competing parties both promoted free market policies such as deregulation, liberalization, and privatization. Measures were adopted in order to attract foreign investment. Overseas Pakistanis were encouraged to invest under special incentives.

Given the frequent changes of government and general political and economic instability during the 1990s, real GDP growth averaged 4.6 percent 
with the agriculture and manufacturing sectors contributing 4.4 percent and 4.8 percent, respectively. Overall investment and national savings as a percentage of GDP were 18.3 and 13.8 percent, respectively and showed a decrease from the levels witnessed during the 1980s. The fiscal deficit remained high at 7 percent of GDP, partially due to a reduction in the tax-toGDP ratio, which fell from around 14 percent in the 1980s to 13.4 percent in the 1990s. The current expenditure of the government as a percentage of GDP also increased from 17.6 percent in the 1980 s to 19.4 percent in the 1990s. This deterioration in fiscal position in turn brought down development spending on infrastructure as well as in social sectors such as education and health. As a percentage of GDP, development expenditure decreased from an average of 7.3 percent in the 1980 s to 4.7 percent in the $1990 \mathrm{~s}$.

The process of trade liberalization, which initially included a reduction in tariff rates, was initiated in the 1990s. Overall trade performance improved in comparison to the 1980s. The export-to-GDP ratio increased to 13 percent while imports as a percentage of GDP exhibited a decline and averaged 17.4 percent. The trade deficit came down to 4.4 percent of GDP. After 1999 economic policies resulted in declining foreign exchange reserves, stalled investment activity, and the mounting debt of public sector corporations. During the next two years Pakistan tried to secure short-term stabilization funds at an expensive interest rate term structure.

In the post 2001 milieu, Pakistan experienced medium-term economic gains and GDP growth was soon restored. The manufacturing sector took a leading role and grew at an average of 8.6 percent between 2000 and 2007. The investment-to-GDP ratio was restored to its 1980s level, averaging 18.6 percent, only this time financed by relatively higher national savings (17.9 percent of GDP). Rising workers' remittances touched record levels. The average growth in remittances during this period was almost 29 percent per annum. The current account deficit as a percentage of GDP was 0.8 percent. The average trade deficit as a percentage of GDP was 3 percentage points lower than the level observed in both previous decades. 
Table-2: Structure of Trade

\begin{tabular}{lcccc}
\hline & 1970s & 1980s & 1990s & 2000-07 \\
\cline { 2 - 5 } & \multicolumn{4}{c}{ Annual Average } \\
\hline \% Share in Imports & 35.6 & 33.6 & 35.8 & 31.8 \\
Capital Goods & 21.1 & 15.5 & 15.2 & 11.1 \\
Consumer Goods & 8.1 & 6.6 & 6.0 & 6.6 \\
Raw Material for Capital Goods & 34.6 & 44.4 & 43.0 & 50.5 \\
Raw Material for Consumer Goods & & & & \\
\% Share in Exports & 39.7 & 33.1 & 14.6 & 11.3 \\
Primary Commodities & 20.9 & 15.9 & 21.7 & 12.4 \\
Semi-Manufactured Goods & 39.6 & 51 & 63.7 & 76.4 \\
Manufactured Goods & & &
\end{tabular}

Source: Economic Survey of Pakistan 2007-08.

Table-2 exhibits the structure of imports and exports. The share of capital goods in overall imports has remained more or less constant since the 1970s, averaging between 31 and 36 percent, while the share of consumer goods has declined from 21 percent in the 1970s to 11 percent during 2000-07. The import of raw material for the production of capital goods has been on the decline while the share of raw material for consumer goods increased and averaged around 51 percent during 2000-07. On the export side the share of primary commodities decreased substantially from 40 percent in the 1970 s to 11 percent during 2000-07. The encouraging aspect is that the share of manufactured goods increased to 76.4 percent, indicating a movement toward achieving value addition in the export structure. 
Table-3: Growth in Imports

\begin{tabular}{lcccc}
\hline & 1970s & 1980s & 1990s & 2000-07 \\
& \multicolumn{4}{c}{ Annual Average } \\
\cline { 2 - 5 } & \multicolumn{4}{c}{ Growth (\%) } \\
\hline Chemicals* & 19.2 & 36.9 & 16.8 & 17.3 \\
Medicines & 30.8 & 18.9 & 15.1 & 9.6 \\
Dyes/Colors & 5.1 & 16.8 & 17.0 & 11.0 \\
Chemical Fertilizers & 82.6 & 16.0 & 27.3 & 13.9 \\
Electrical Goods & 12.8 & 12.1 & 9.1 & 25.1 \\
Machinery & 15.4 & 20.7 & 14.1 & 24.2 \\
Transport Equipment & 27.1 & 15.9 & 16.6 & 29.1 \\
Paper/Board & 22.4 & 18.9 & 8.6 & 18.8 \\
Tea & 22.9 & 15.6 & 16.6 & 2.5 \\
Art-Silk Yarn & 206.9 & 9.8 & 1.5 & 29.2 \\
Iron/Stee1 & 17.5 & 11.7 & 11.6 & 24.3 \\
Non-Ferrous Metals & 60.5 & 21.4 & 11.0 & 25.8 \\
Petroleum & 12.1 & 17.6 & 16.2 & 31.1 \\
Edible Oils & 45.5 & 17.0 & 21.2 & 8.7 \\
Grains & 66.8 & 46.9 & 24.5 & 25.5 \\
Other Imports & 15.1 & 14.5 & 16.6 & 22.2 \\
\hline
\end{tabular}

Source: Economic Survey of Pakistan.

*The data for group-wise imports is from 1976 under Statistical Supplement to the Economic Survey 2006.

Table-3 shows the decade-wise percentage growth in imports. In comparison to the 1970s, there is a shift away from necessary items toward those used in the production process. Growth in the import of food items such as edible oils, grains, and tea is declining over time. There is an increase in the import of capital goods and industrial inputs such as electric goods, machinery, transport equipment, iron/steel, and petroleum.

Since the early 1990s, governments have continuously reduced tariff rates to facilitate the cheap import of raw material and to pass on the effects of free trade onto consumers. The maximum tariff was brought down to 25 percent in 2003 from 92 percent in 1993. During the same period, the number of tariff slabs was reduced from 13 to 4 . The role of excise duties in the overall taxation structure has been minimized. 


\section{Model, Data, and Simulations}

\section{CGE-Microsimulation Model}

The CGE model follows the framework in Lofgren, et al. (2001) and Dervis, et al. (1982). The model is tailored for the commonly observed specifications of a developing country. Some of the important features of low- and middle-income countries included in this model are: (a) household consumption of nonmarketed commodities, (b) the explicit treatment of transaction costs for marketed commodities, and (c) a separation of production activities and commodities (which allows an activity to produce multiple commodities and any commodity can be produced by multiple activities). The detailed model equations are given in Annex B.

The production and consumption decisions are modeled using nonlinear optimality conditions, i.e., production and consumption decisions are based on the maximization of profits and utility, respectively (subject to the underlying budget constraints). Production technology at the top of the nest uses a CES specification. The value addition has been treated as a CES function of primary inputs while the overall intermediate input is a Leontief function of disaggregated intermediate inputs. Fixed yield coefficients determine whether an activity produces one or multiple commodities. The aggregate revenue from an activity is then a function of the level of activity, yield, and the producer prices of commodities. The factor market follows the microeconomic assumption of employing factors until the point where the marginal revenue product of a particular factor becomes equal to its wage. Factor wages are variable across activities in order to realistically portray cases where: (a) markets are segmented, (b) factors are mobile, and (c) both the abovementioned possibilities exist. The activity-specific wage is calculated by multiplying the wage by a distortion value. The distortion value will be different across activities.

The overall domestic output from all activities is allocated between domestic turnover and exports. In this case, the assumption of imperfect transformability between exports and domestically sold goods is established using a CET function. Similarly, on the import side, a CES function is used to model imperfect sustainability (also referred to as the Armington assumption).

Households receive (a) income from factors via enterprises, and (b) transfers from other institutions such as the government and the rest of the world. A household's income is exhausted by (a) consumption, (b) savings, (c) paying income tax, and (d) transfer payments to other institutions. Household consume two types of commodities that include marketed 
commodities which are accounted at their market price (which includes indirect taxes and transactions costs) and home-produced commodities accounted at producer prices. A linear expenditure system (LES) demand function is used to allocate consumption across commodities.

The income received by enterprises is allocated among savings, payment of corporate (direct) taxes, and transfers. The government receives taxes at fixed ad valorem rates and has a fixed consumption level. Those taxes that are charged on a specific basis enter the model after conversion to ad valorem equivalents. However, transfer payments made by the government to households and enterprises are indexed to the CPI. The residual from the government's income and consumption is treated as savings. Given that the government savings are flexible, direct tax rates are fixed in order to bring about government sector closure in the model. The payments made by the rest of the world to domestic institutions (government, households, and enterprises) and factors are treated as fixed. The exchange rate is flexible. The CPI is regarded as a numeraire. The model has investment-driven savings where capital formation is fixed and there is uniform change in the marginal propensity to save for selected institutions. Land and labor are fully employed and allowed mobility across sectors. Capital is also fully employed, however it is activity-specific, i.e., there is no mobility across sectors.

For the micro-simulation model we estimate earnings equations and an occupational choice model following the convention in Alatas and Bourguignon (2005). Earnings equations were estimated for various categories, namely ${ }^{1}$ : (a) labor on a large farm, (b) labor on a medium farm in Sindh, (c) labor on a medium farm in Punjab, (d) labor on a medium farm in the rest of Pakistan, (e) labor on a small farm in Sindh, (f) 1abor on a small farm in Punjab, (g) labor on a small farm in the rest of Pakistan, (h) wage employment in agriculture, (i) nonagricultural unskilled wage earner, and (j) nonagricultural skilled wage earner.

We obtained predicted earnings from the above earnings functions and used them (among other characteristic variables) ${ }^{2}$ as independent variables in maximum likelihood multinomial logit regressions, thus allowing individual occupational choice to be influenced by returns on other activities and regions. This possibility translates from the macro-model where we explained earlier that CGE model closure for the labor market allows mobility of labor across activities.

\footnotetext{
${ }^{1}$ In most cases a two-step Heckman procedure was adopted. However for the profit function, an instrumental variables regression was estimated.

${ }^{2}$ Other variables include: age, age squared, province, marital status, number of persons in the household, and type of dwelling.
} 
Linking macro- and micro-models has recently gained a lot of attention in the literature. The three channels that affect income distribution are: (a) changes in factor returns, (b) changes in prices, and (c) changes in capital gains (see Bourguignon et a1. 1991). The micro-macro models in this paper were linked in a top-down fashion as shown in Bourguignon, Robilliard and Robinson (2003), which also provides details on how consistency is achieved between the SAM and household data. These data consistency requirements are an essential aspect of this top-down exercise, which allows us to link factor returns, prices, and employment in the CGE model with the corresponding household level variables in the micro-data. This approach has been used in Bussolo and Lay (2006), Herault (2005), Coady and Harris (2004), and Vos and De Jong (2003).

\section{Data and Measurement Issues}

The data for our CGE model has been derived from an existing SAM for 2002 documented in Dorosh, Niazi, and Nazli $(2004)^{3}$. This SAM has been furnished by five different data sources. First, we use the input-output table that provides information mainly on activities and commodity accounts. Second, the national accounts data is used to compile information on value addition in fifteen sectors. Third, the Pakistan Integrated Household Survey is used to disaggregate consumption. Fourth, the Pakistan Rural Household Survey 2001 conducted by the Pakistan Institute of Development Economics is used to disaggregate household incomes. Finally, the Pakistan Economic Survey 2001-02, published by the Ministry of Finance provides sector-wise and commodity-wise data on production, prices, and trade.

On the activities side, the matrix includes payments and receipts for 12 agricultural sectors, 16 industrial sectors, and 6 services sectors. Similar sectoral detail follows in the commodity accounts, which makes the mapping between activities and commodities easier. Factor accounts include labor, land, and capital, with labor disaggregated into 10 different categories. This categorical disaggregation is based on the criteria of farm size, agriculture/non-agriculture wage, and unskilled/skilled labor. Land, again, is disaggregated according to farm size (in different provinces). Capital is categorized into livestock, other agriculture, and informal and formal

\footnotetext{
${ }^{3}$ Ideally, a more recent SAM should have been used. However, given the delay at the Federal Bureau of Statistics in finalizing the latest input-output table, we were forced to use the data for 2002. As we are working with relative changes in a CGE model, the underlying relationships between production sectors and institutions remain relevant in the medium term. The structural changes in developing countries are not rapid therefore we may consider these SAM estimates reliable. All results should be interpreted in terms of 2001/02 prices.
} 
capital. Household accounts are distributed into rural and urban with rural households being further classified into 17 categories based on farm size and rural poor/rural non-poor. Urban households have been classified into poor and non-poor. Other institutions in the SAM include enterprises, the government, and the rest of the world account.

In terms of factor shares in income, 39 percent of household income comes from labor, 21 percent from informal capital, 9 percent from agricultural capital, 6 percent each from land and transfers, and the remaining 19 percent from other sources. The share of rural and urban households in overall income is 44.8 and 55.2 percent, respectively.

The main data source for the microsimulation model is the Pakistan Integrated Household Survey 2001/02 which includes income and expenditure details for 16,400 households. The average monthly income in the benchmark data is Rs. 7,168 per month, with quintiles 1 and 5 earning Rs. 4,391 and Rs. 11,360, respectively. Incomes falling under selfemployment account for the major portion (41.3\%) followed by wages and salaries (33.5\%). Average expenditure is Rs. 6,714 with quintiles 1 and 5 spending Rs. 4,004 and Rs. 10,334, respectively. Food and beverages occupy a 48.3 percent share in overall spending, although the share of food declines by 17.2 percent when one moves from the lowest to highest quintiles.

The selection of free parameters/elasticities poses a potential problem. Some studies that provide trade, production, and consumption elasticities for the Pakistan economy include Deaton (1997), Kemal (1979), and Dorosh et a1. (2002). However, in cases where econometrically estimated elasticities for Pakistan are not available, we have selected our values keeping in line with studies conducted for comparable developing economies. The trade and production elasticities are given in Annex-A.

The structure of value addition is such that livestock (cattle and dairy) contributes 10.3 percent; major crops, fruits and vegetables contribute around 12 percent; textiles 3.6 percent; energy 3.4 percent; construction 3.6 percent; transport 12 percent; housing 4.8 percent; and wholesale and retail trade 15 percent toward overall value addition. The total share of the agricultural sector in exports is around 4 percent, while industry stands at 79 percent with the leading subsectors being textile, lint, and yarn. The services sector contributes 17 percent to exports, mainly in the transport and communication subsectors. The total share of the agricultural sector in imports is around 3 percent while industry's share is 92 percent. The services sector contributes 5 percent to imports, mainly in private services subsectors. 


\section{Simulation Design}

In the post-2001 milieu, the current account deficit of Pakistan was transformed into a surplus in one of the shortest periods in economic history. This was largely due to factors such as an increase in remittances, unilateral transfers, and export receipts. However, the current account deficit (and the composition of this deficit) has once again become a problem for the domestic economy. This is attributable to an increase in import prices which in turn has increased the domestic cost of production and therefore hampers export competitiveness. Pakistan allowed a subsidy in the wake of rising oil and food prices, but this can only be a short term measure given the substantial size of this transfer payment which, if maintained in the medium- to long-term, might increase the budgetary deficit and thereby bringing about another spiral of inflation.

In our experiments, we study the impacts of two current account shocks that have had opposite impacts on the economy (at least in broad macroeconomic terms). First, there is the inflow of foreign savings, required by developing countries to augment domestic savings and hence finance their infrastructure and social sector requirements. Since 2002, the increased inflow of capital led to an appreciation in the value of domestic currency which favored imports. In our model, we will increase overall foreign savings by 50 percent and determine their impact at the macro and micro level. Second, there are the changes in import prices that in turn impact prices faced by local producers and consumers, thereby altering welfare levels in the economy. The imported goods that are integrated into the production process not only influence growth and competitiveness, but also impact productivity in the form of spillover benefits. Coe, Helpman and Hoffmaister (1997) estimate that if the import share of machinery and equipment to GDP increases by 1 percent, total factor productivity increases by 0.3 percent.

An outline of our policy experiments is as follows:

\begin{tabular}{ll}
\hline Simulations & \multicolumn{1}{c}{ Description } \\
\hline Sim-1 & 50 percent increase in foreign savings \\
Sim-2 & 10 percent increase in the import price of petroleum \\
Sim-3 & 10 percent increase in the import price of industrial raw \\
& material \\
\hline
\end{tabular}

Closure rules remain the same for all simulations. For the factor market, we assume labor to be fully employed and mobile across activities. The same closure is retained for land. Capital is fully employed and activity- 
specific. We have investment-driven savings where the marginal propensity to save is allowed to change for selected institutions. Government savings are flexible and the direct tax rate is fixed. The CPI is treated as a numeraire (i.e., fixed) and the index of domestic producer prices is flexible. The exchange rate is also flexible.

We have sequenced our results below such that in every simulation, macroeconomic results (providing aggregate demand, investment, and consumption) are followed by changes in prices and wages. We then see the impact of the changed price structure on the disaggregated value addition (in all activities given in the SAM), import demand and export supply. In our case, given the assumption of full employment, macroeconomic changes do not impact the employment levels (however inter-sectoral changes in labor demand are allowed). We continue our analysis and see how changed production patterns impact household consumption expenditure and overall welfare. Finally, we see the impact of simulations on poverty and inequality.

\section{Results-I: Increase in Foreign Savings}

Our macroeconomic results for the abovementioned experiments are given in Table-4. In Sim-1, a 50 percent increase in foreign savings leads to an increase in real private consumption by 2.8 percent. Given the larger amount of foreign exchange available, imports increase by 3.7 percent while exports decline by 6.5 percent. The decline in exports indicates deterioration in the trade balance. We observe that the trade deficit as a percentage of nominal GDP increases by 1.8 percent. In nominal terms, the foreign savingsto-GDP ratio increases by 2 percent while the investment- and private savings-to-GDP ratios decline by 0.3 and 2.4 percent, respectively.

These results, if seen in the light of economic theory, suggest that foreign savings can significantly alter the real exchange rate, which in turn causes the trade balance to change. This also implies that the production of domestically consumed goods will be altered. This happens in our results because absorption, which is defined as total domestic spending on a good calculated at the prices paid by domestic demanders, increases by 2.2 percent in real terms. This increase, to some extent, is made possible through the domestic (non-tradable) price index, which is decreasing.

The impact of simulations on value added and output price is given in Table-5. Value-added prices decline mostly for tradable goods. The sectors showing the highest decline are: leather $(10$ percent $)$, cotton lint/yarn (7.1 percent), and manufacturing $(6.9$ percent $)$. The prices of several large sectors show an increase, such as livestock, wheat milling, 
housing, and private services. These are mostly non-tradable sectors. The direction of change is similar in the case of output prices, but the magnitude of these changes is much smaller, given the inclusion of other factors in output prices. Such a change seems pro-poor given that the prices of food and oil show a decline. However, the price of housing increases by 6.9 percent in the case of value added price and 5.5 percent in the case of output price. The decreased prices of cotton and textiles also indicate increasing export competitiveness, although we know from the macroeconomic results above, that overall exports did not increase because of an exchange rate appreciation.

The returns to labor with farm holdings and returns to land decline (Table-6). The return to capital does not change given our closure assumptions. Those who gain under this change are agricultural wage labor and nonagricultural unskilled wage labor, whose wages increase by 1.5 percent and 0.5 percent, respectively. It is broadly recognized that agricultural wage workers are regarded as the poorest of the rural poor (ILO, 1996). Overall agriculture incomes are the second most important source, with almost 27 percent of total per capita household income (see Adams 1995). According to the Labor Force Survey, around 44 percent of the employed (10 years age and above) are working in the agriculture, forestry, and fishing sectors. Given these statistics, it seems that our simulation results indicate a redistribution within the agriculture sector, where the returns for farm owners are declining and the wages for employed labor in agriculture are increasing. The increase in the wages of nonagricultural unskilled labor also indicates a change in favor of the urban poor. However, we cannot ascertain the magnitude as the SAM data (in its present form) is not divided by urban/rural classification.

The return to land declines for all land classifications in the model. The returns for non-irrigated land decline more than irrigated land, and within the latter, the decline is greater for large and medium farms in Punjab.

The impact on value added can be seen in Table-7. These results are mixed not only across but also within sectors. In most sectors, the value addition declines or sees no change. The decline in the industrial sector's value addition is greater than that of the agricultural sector. In the case of agriculture, there is a marginal increase in value added in wheat, sugar cane, fruits, vegetables, and livestock. However, there is a decline in rice, forestry, and fishing. For the industrial sector, there is a general decline in value addition except for the cement, energy, vegetable oils, and wheat milling sectors. 
We should also go on to analyze the sector-wise impact on imports and exports. In Table-8, we show disaggregated changes in the quantity of imports. The increase in foreign savings leads to an increase in imports for all sectors (except a marginal decline in the mining sector). This is primarily due to exchange rate depreciation (see Table-4). The highest increase is in leather, textiles, commerce, and livestock (cattle).

The impact on Pakistani exports is shown in Table-9. Increased foreign savings lead to a worsening of exports across all sectors and particularly in textiles, leather, cement, transport, rice, and livestock. Exports in value terms decline given the increase in output prices, which make exports relatively uncompetitive abroad.

In evaluating changes in welfare, we first examine how household incomes change for our simulations. These results can be seen in Table-10. We observe that the change mimics what we have seen for changes in factor returns (Table-6). When foreign savings increase, large or medium farms are the main losers, while all other household groups gain, most notably rural agricultural workers who are landless and small farm owners. As explained above, this also represents a redistribution in favor of low-income households. Household consumption, however, increases for all groups (Table-11). The increase is greater for rural workers.

Our micro-simulation results are given in Table-12. In line with the household welfare impact explained above, poverty decreases by 3.1 percent when foreign savings increase by 50 percent. The poverty gap and severity both show a decline. Poverty decreases in all provinces with Punjab having the highest decline by almost 3.3 percent followed by Sindh ( 2.8 percent).

The gini coefficient declines by 0.3 percent. If aversion to inequality is taken in to account, we see that the Atkinson index shows a larger decline for the top end of the distribution. As the inequality aversion parameter increases beyond 0.5 , there is a smaller decline in the Atkinson index (measured in percentage terms). We also compute the percentile ratios for the distribution of post-shock incomes. The $\mathrm{p} 90 / \mathrm{p} 10$ is the decile ratio, $\mathrm{p} 75 / \mathrm{p} 25$ relates to the middle part of the distribution and $\mathrm{p} 90 / \mathrm{p} 50$ shows the dispersion in the upper tail. In Table-12, the largest decrease is in the p90/p10 ratio, whereas the decrease is less than half this in the middle part of the distribution.

\section{Results-II: Increase in Import Prices}

Going back to theory, we understand that the domestic effects of an import price increase will be broadly similar to an increase in tariffs (see Go 
1991). Viewed in the context of overall world prices, the Stolper-Samuelson theorem suggests that a rise in the relative price of a good will lead to a rise in the return to that factor which is used most intensively in the production of the good (and a fall in the return to the other factors). This theorem has been derived from the basic Heckscher-Ohlin model which is a general equilibrium model of international trade and shows that a country will export products that utilize its abundant factors of production and import products that employ a country's scarce factors and resources. A corollary to the Stolper-Samuelson theorem is the factor price equalization theorem which tells us that, regardless of factor mobility across international borders, factor prices tend to equalize for countries that do not differ in technology. ${ }^{4}$

We can see in Table- 4 that a 10 percent increase in the import price of petroleum ${ }^{5}$ (Sim-2) brings about a 0.7 percent decline in GDP. Private consumption declines by 4.3 percent. As a percentage of nominal GDP, investment and private savings increased by 1.1 percent. The current account deficit as a percentage of nominal GDP also increases by 0.2 percent. As expected, the direction of a change in trade decreases both real imports and exports by 11.2 and 1.8 percent, respectively. The overall import price index increases by 11.9 percent. This increase also depends on the weight of the petroleum group in overall imports. In relative terms, the domestic (non-tradables) price index decreases by 1.1 percent, indicating that domestically produced goods are now cheaper. We need to qualify this result by saying that the prices of only those goods will decrease that do not use petroleum intensively as an input in the production process. The world price index for tradable goods increases by 7.2 percent, indicating that Pakistani exports are now relatively expensive. The trade deficit-to-nominal GDP ratio increases by 0.2 percent. Because of declining imports there is an impact on tariff revenue and government savings, both decreasing by 0.2 and 0.3 percent of GDP, respectively.

The impact that an increase in the import price of petroleum has on the economy is greater than any other import commodity group. This is essentially due to the intensity with which this good is used in the production process, as well as by the consumers at the household level, and the knock-on effects that petroleum prices have at the intermediate demand stage.

\footnotetext{
${ }^{4}$ What will be the effect of an increase in the physical endowment of factors? The Rybczynski theorem suggests that an increase in one of the two factors of production leads to a relative increase in the production of the good using more of that factor.

${ }^{5}$ In Pakistan, petroleum imports account for around 24 percent of the overall import bill (Economic Survey of Pakistan 2006-07).
} 
In our next simulation (Sim-3), we increase the price of industrial raw materials (excluding petroleum) by 10 percent. This commodity group includes organic chemicals, inorganic compounds of precious metals, fertilizers, tanning or dyeing extracts, oils, resinoids, perfumery, albuminoidal substances, glues, enzymes, pyrotechnic products, pharmaceutical products, and related goods. An increase in the import price of this group decreases GDP by 0.5 percent where private consumption declines by 2.7 percent. The direction of change in major macroeconomic variables remains the same as in Sim-2. While the decrease in real imports is lower (7.4\%) in comparison to Sim-2, the decrease in real exports is slightly higher $(1.9 \%)$. The nominal exchange rate depreciates by 0.7 percent and the import price index increases by 7.1 percent. Firm incomes decline by 2.5 percent. Government savings and tariff revenues as a percentage of GDP both decrease by 0.2 percent.

Table-6 gives details on how import prices affect domestic prices. In both cases (Sim-2 and Sim-3), we see that external price changes impact the crop sector prices adversely. There is more than a 3 percent increase in the value added prices of wheat, rice, cotton, sugar cane, fruits, and vegetables. Another concern is how these experiments impact the competitiveness of the local manufacturing sector. Output prices increase for cotton lint, yarn, petroleum refining, chemicals, mining, vegetable oil, wood, and other manufacturing. We observe that the sectors relatively insulated from trade shocks see a decline in their prices. The decline is most apparent in poultry, rice milling (Irri/basmati), cement, and public and private services.

In the import price experiment, agricultural wage, nonagricultural unskilled labor, and agricultural skilled labor become the main losers given that activity levels are declining on the production side (Table-6). Returns to land and profits for farm owners increase, showing a change in favor of (agricultural) asset owners. The increase in factor prices is highest for the simulation where the import price of petroleum is increased by 10 percent. In this case, the returns to labor having a small farm increase the most (6.7 percent) followed by labor having a medium-size farm (6.3 percent). A similar pattern is observed in the case of changes in returns to land. The small land category gains the most (7.9 percent) followed by medium-size and large land. In this case one may infer that there is a redistribution taking place among agricultural asset owners, where those with small to medium ownerships are gaining.

As imports become expensive relative to domestically produced goods, there is an expansion in production particularly for nontradable industrial sectors (Table-7). This increases the demand for factor inputs in the beneficiary sectors, which in turn increases factor prices (land and labor 
in our case as they are mobile across sectors). This argument will hold under the full-employment assumption.

The value addition increases for leather, textiles, chemicals, other manufacturing, petroleum refining, wood products and vegetable oil (Table-7). In overall terms, exporting sectors see a small increase or no change in value addition. However two major exports, cotton and rice, decline by 0.6 and 2 percent, respectively.

We also briefly look at the case where we increase the import price of the machinery group by 10 percent. This group includes electrical machinery, appliances, boilers, and related mechanical equipment. The decrease in GDP this time is greater than that in Sim-3 (decreases by almost 0.7 percent) and the decline in consumption is also greater ( 3.9 percent). However this decrease is again less than what we have seen for the case of petroleum (Sim-2). The magnitude of change in the case of import price shocks for different commodity groups shows that a 10 percent increase in the import price of petroleum and a 10 percent increase in the import price of machinery lead to almost the same level of change.

In line with our expectations, import price changes lead to a decline in imports in all sectors (Table-8). In both simulations for an increase in import prices, the manufacturing sector is the worst affected as this sector is relatively more dependent on imported inputs. The decline in imports is substantial in the case of vegetable oil, followed by declining imports in leather, textiles, and sugar. Such a change causes concern for overall production in the country because the imported content (particularly in developing countries) is indispensable for activities with lower Armington elasticities. ${ }^{6}$ In the case of Pakistan, exports also embody a high degree of imported content.

The impact of import price increases on the value of exports seems mixed (Table-9). The depreciation of the nominal exchange rate causes exports to increase. However, export sectors, particularly those with a high imported content (as inputs), face a decline in output. An increase in the import price of petroleum has a positive effect on textile exports, while an increase in the import price of industrial raw material has a negative effect. A similar trend is observed for rice, leather, and wheat milling.

The redistribution results seen in the previous section are reversed in the case of import price shocks (Table-10), where only those households who

\footnotetext{
${ }^{6}$ This is the degree of substitutability between domestic and imported sources of supply. A higher value for Armington implies a higher possibility of substitution and vice versa.
} 
own large and medium farms see an increase in their incomes. All other groups face a decline. As explained above, these changes follow what we have seen for changes in factor returns (Table-6). The same pattern evolves in the case of household consumption in Table-11. The negative impact of an import price increase on middle- and low-income groups indicates how consumer surplus is sharply reduced via the increase in domestic prices. We had seen earlier that the output price of mostly necessity items had increased. This included food and petroleum prices, items intensively used in consumption by low-income groups. We can see a one-to-one mapping of results for household income and expenditure. It cannot be stated with certainty that import price changes act in a manner similar to a regressive tax, because in Table-10 we observe that urban non-poor and rural nonfarm non-poor households also witness a decrease in their income level. This result seems logical as farm owners least use the commodity groups that have seen changes in import prices. Farm owners also have a low level of imported inputs in their output compared with industrial producers. In the case of an oil price hike, an increase in the import price of raw materials (such as chemicals), or import price of machinery, one can expect farm owners to remain insulated to some extent. In the case of Pakistan, this exhibits the low level of mechanization in the agriculture sector.

The import price increase leads to an increase in poverty level and inequality (Table-12). In the case of a 10 percent increase in the import price of petroleum, poverty increases by 4.1 percent and inequality worsens by 0.4 percent. For a 10 percent increase in the import price of industrial raw material, poverty increases by 3.4 percent and inequality worsens by 0.2 percent. Sindh is the worst affected where the headcount ratio increases by more than 6 percent under both simulations.

\section{Conclusion}

In this paper, we have studied the general equilibrium and microlevel impacts of (a) an increase in foreign savings, (b) an increase in the import price of petroleum, and (c) an increase in the import price of industrial raw material. An increase in foreign savings leads to an increase in imports and a decrease in exports. The main sectors facing a decline in exports are textiles, leather, cement, and livestock. The prices of nontradable goods decline. Changes in price seem pro-poor as food and oil prices also decrease. The returns to labor with farm holdings and returns to land decline. The returns to non-irrigated land declines more than irrigated land. Those factors that gain under this change are agricultural wage labor and nonagricultural unskilled wage labor, the latter indicating a change in favor of the urban poor. Poverty decreases and there is some improvement in income distribution. 
Increases in the import prices of petroleum or industrial raw material lead to a reduction in imports and exports (the magnitude of the former is greater). The competitiveness of local manufacturing is damaged as output prices increase for cotton lint, yarn, petroleum refining, and chemicals. Sectors relatively insulated from import shocks, e.g., rice and poultry, see a decline in their prices. In terms of factor returns, agricultural wage earners, nonagricultural skilled labor, and nonagricultural unskilled labor become the main losers given the decline in production activity. Returns to land and profits to farm owners increase, showing a change in favor of agricultural asset owners. Poverty increases by over 3 percent.

Among the abovementioned simulations, external oil price shocks have the greatest potential to impact the socioeconomy. Import price changes in comparison to changes in foreign savings have opposite effects at both the micro and macro levels. 


\section{Tables - Results}

Table-4: Macroeconomic Changes (\% Change over Base)

\begin{tabular}{|c|c|c|c|c|}
\hline & BASE & Sim-1 & Sim-2 & Sim-3 \\
\hline GDP (mp) & $3645^{*}$ & 0.1 & -0.7 & -0.5 \\
\hline Private Consumption & 3053 & 2.8 & -4.3 & -2.7 \\
\hline Real Absorption (LCU at Base Prices) & 4001 & 2.2 & -3.3 & -2.1 \\
\hline Tota1 Real Exports (LCU At Base Prices) & 692 & -6.5 & -1.8 & -1.9 \\
\hline Total Real Imports (LCU At Base Prices) & 1054 & 3.7 & -11.2 & -7.4 \\
\hline Enterprise Income & 798 & -0.8 & -3.3 & -2.5 \\
\hline PPP Real Exchange Rate (LCUs per FCU) & 99 & -4.0 & 8.4 & 4.5 \\
\hline Nominal Exchange Rate (LCUs per FCU) & 102 & -4.1 & & -0.7 \\
\hline Imports Price Index (FCU -- 100 for Base) & 100 & & 11.9 & 7.1 \\
\hline $\begin{array}{l}\text { World (tradables) Price Index (FCU -- } 100 \\
\text { for base) }\end{array}$ & 100 & & 7.2 & 4.3 \\
\hline $\begin{array}{l}\text { Domestic (non-tradables) Price Index (100 } \\
\text { for Base) }\end{array}$ & 103 & -0.1 & -1.1 & -0.9 \\
\hline $\begin{array}{l}\text { Terms of Trade (ratio pwe index \& pwm } \\
\text { index) ( } 100 \text { for Base) }\end{array}$ & 100 & & -10.7 & -6.7 \\
\hline Investment (\% of nominal GDP) & 14 & -0.3 & 1.1 & 0.5 \\
\hline $\begin{array}{l}\text { Private (Household + Enterprise) Savings (\% } \\
\text { of Nominal GDP) }\end{array}$ & 16 & -2.4 & 1.1 & 0.6 \\
\hline Foreign Savings (\% of Nominal GDP) & 5 & 2.0 & 0.2 & 0.1 \\
\hline Trade Deficit (\% of Nominal GDP) & 11 & 1.8 & 0.2 & \\
\hline Government Savings (\% of Nominal GDP) & -6 & 0.1 & -0.3 & -0.2 \\
\hline Tariff Revenue (\% of Nominal GDP) & 1 & & -0.2 & -0.2 \\
\hline
\end{tabular}

*In real rupees billion

**LCU: local currency unit, FCU: foreign currency unit.

***Sim-1: 50 percent increase in foreign savings, Sim-2: 10 percent increase in import price of petroleum, Sim-3: 10 percent increase in import price of industrial raw material 
Table-5: Changes in Prices

\begin{tabular}{|c|c|c|c|c|c|c|}
\hline & \multicolumn{3}{|c|}{$\begin{array}{c}\text { Value Added Price } \\
\text { (\% Change over Base) }\end{array}$} & \multicolumn{3}{|c|}{$\begin{array}{c}\text { Output Price } \\
\text { (\% Change over Base) }\end{array}$} \\
\hline & Sim-1 & Sim-2 & Sim-3 & Sim-1 & Sim-2 & Sim-3 \\
\hline Wheat Irrigated & -1.9 & 4.0 & 3.1 & -1.8 & 3.9 & 2.7 \\
\hline Wheat Non-Irrigated & -3.0 & 3.7 & 2.1 & & & \\
\hline Paddy IRRI & -2.8 & 5.8 & 4.6 & -2.3 & 5.0 & 3.7 \\
\hline Paddy Basmati & -2.6 & 6.2 & 5.1 & -2.2 & 5.3 & 4.0 \\
\hline Cotton & -3.3 & 6.2 & 4.9 & -3.0 & 6.5 & 4.7 \\
\hline Sugarcane & -2.1 & 5.8 & 4.8 & -2.0 & 5.5 & 4.2 \\
\hline Other Major Crops & -2.6 & 6.1 & 4.8 & -2.1 & 4.9 & 3.8 \\
\hline Fruits/ Vegetables & -2.5 & 7.9 & 6.7 & -1.7 & 4.9 & 4.2 \\
\hline Livestock/Cattle/Dairy & 4.5 & -5.1 & -2.7 & 2.0 & -2.3 & -1.0 \\
\hline Poultry & 5.4 & -7.7 & -4.5 & 2.2 & -3.0 & -1.6 \\
\hline Forestry & -3.9 & 3.2 & 1.1 & -3.3 & 2.9 & 1.1 \\
\hline Fishing Industry & -3.1 & -1.4 & -1.4 & -2.0 & -0.8 & -0.9 \\
\hline Mining & -5.4 & 7.2 & 2.1 & -4.0 & 5.1 & 1.4 \\
\hline Vegetable Oil & 0.5 & 43.9 & 44.4 & -0.8 & 6.3 & 6.1 \\
\hline Wheat Milling & 5.4 & -13 & -9.1 & 0.3 & -1.4 & -1.0 \\
\hline Rice Milling IRRI & -3.4 & -7.2 & -6.0 & -2.0 & -0.6 & -0.7 \\
\hline Rice Milling Basmati & -0.7 & -9.7 & -7.5 & -1.2 & -1.1 & -0.9 \\
\hline Sugar & 4.3 & -10 & -7.0 & 0.9 & -2.9 & -1.9 \\
\hline Other Food & -5.8 & 1.3 & 0.2 & -2.7 & 0.5 & 0.1 \\
\hline Cotton Lint/Yarn & -7.1 & -4.3 & -4.1 & -3.5 & 1.5 & 0.6 \\
\hline Textiles & -4.7 & -3.7 & -2.8 & -2.5 & -0.1 & -0.5 \\
\hline Leather & -10 & 1.8 & 0.4 & -0.5 & -1.0 & -0.7 \\
\hline Wood Products & -4.6 & 5.1 & 1.5 & -2.7 & 2.9 & 0.8 \\
\hline Chemicals & -4.7 & 12.3 & 8.3 & -2.8 & 6.3 & 3.6 \\
\hline Cement/Bricks & 4.5 & -9.7 & -6.0 & 1.9 & -4.8 & -3.5 \\
\hline Petroleum Refining & -3.9 & 10.9 & 5.8 & -2.6 & 4.5 & 1.5 \\
\hline Other Manufacturing & -6.9 & 4.4 & 1.7 & -3.5 & 4.2 & 1.7 \\
\hline Energy & 0.2 & -5.8 & -3.9 & -0.7 & -2.6 & -2.3 \\
\hline Construction & -0.2 & -4.5 & -3.1 & -0.6 & -1.1 & -1.3 \\
\hline Commerce & 0.3 & -4.2 & -2.8 & 0.4 & -4.0 & -2.7 \\
\hline Transport & 0.9 & -6.9 & -4.5 & -0.5 & -1.8 & -1.7 \\
\hline Housing & 6.9 & -12 & -7.7 & 5.5 & -9.5 & -6.4 \\
\hline Private Services & 0.8 & -4.7 & -3.4 & 0.5 & -3.3 & -2.5 \\
\hline Public Services & -0.8 & -4.1 & -2.9 & -0.8 & -2.7 & -2.2 \\
\hline
\end{tabular}

* Represents average output price.

** Sim-1: 50 percent increase in foreign savings, Sim-2: 10 percent increase in import price of petroleum, Sim-3: 10 percent increase in import price of industrial raw material 
Table-6: Factor Wages / Returns (\% Change from Base)

\begin{tabular}{lccc}
\hline & Sim-1 & Sim-2 & Sim-3 \\
\hline Labor_Large Farm & -3.1 & 4.9 & 3.5 \\
Labor_Medium Farm_Sindh & -3.1 & 6.0 & 4.5 \\
Labor_Medium Farm_Punjab & -3.3 & 6.5 & 5.0 \\
Labor_Medium Farm_Other Pakistan & -2.2 & 3.5 & 2.4 \\
Labor_Small Farm_Sindh & -3.1 & 6.3 & 4.9 \\
Labor_Small Farm_Punjab & -2.8 & 6.7 & 5.4 \\
Labor_Small Farm_Other Pakistan & -2.7 & 6.7 & 5.1 \\
Labor_Agricultura1 Wage & 1.5 & -1.5 & -0.5 \\
Labor_Non_Agricultural Wage Unskilled & 0.5 & -4.9 & -3.3 \\
Labor_Non_Agricultural Wage Skilled & -0.8 & -4.1 & -2.9 \\
Land_Large Farm_Sindh & -2.4 & 4.5 & 3.5 \\
Land_Large Farm_Punjab & -3.0 & 5.5 & 4.0 \\
Land_Large Farm_Other Pakistan & -3.6 & 2.6 & 0.8 \\
Land_Irrigated_Medium Farm_Sindh & -2.8 & 6.6 & 5.2 \\
Land_Irrigated_Medium Farm_Punjab & -2.9 & 7.2 & 5.9 \\
Land_Irrigated_Medium Farm_Other & -2.0 & 4.6 & 3.6 \\
Pakistan & -2.8 & 7.3 & 6.0 \\
Land_Irrigated_Small Farm_Sindh & -2.6 & 7.9 & 6.7 \\
Land_Irrigated_Small Farm_Punjab & -2.4 & 7.9 & 6.5 \\
Land_Irrigated_Small Farm_Other Pakistan & -4.4 & 2.7 & 0.1 \\
Land_Non_Irrigated_Small Farm_Sindh & -4.2 & 2.7 & 0.3 \\
Land_Non_Irrigated_Small Farm_Punjab & -5.2 & 2.5 & -0.5 \\
Land_Non_Irrigated_Small Farm_Other & & & \\
Pakistan & & & \\
\hline
\end{tabular}

Sim-1: 50 percent increase in foreign savings, Sim-2: 10 percent increase in import price of petroleum, Sim-3: 10 percent increase in import price of industrial raw material 
Table-7: Quantity of Value Added (\% Change from Base)

\begin{tabular}{|c|c|c|c|c|}
\hline & BASE & Sim-1 & Sim-2 & Sim-3 \\
\hline Wheat Irrigated & 63 & 0.7 & -2.6 & -2.3 \\
\hline Wheat Non-Irrigated & 4 & 2.5 & -0.1 & 1.1 \\
\hline Paddy IRRI & 9 & -0.8 & -0.9 & -0.9 \\
\hline Paddy Basmati & 17 & -0.1 & -1.9 & -1.6 \\
\hline Cotton & 49 & -2.7 & 0.1 & -0.3 \\
\hline Sugarcane & 35 & 1.8 & -2.2 & -1.5 \\
\hline Other Major Crops & 96 & -0.5 & 0.4 & -0.2 \\
\hline Fruits/ Vegetables & 123 & 0.2 & 2.9 & 2.9 \\
\hline Livestock/Cattle/Dairy & 347 & 0.3 & -0.3 & -0.2 \\
\hline Poultry & 24 & 0.4 & -0.6 & -0.4 \\
\hline Forestry & 10 & -1.8 & -0.7 & -1.7 \\
\hline Fishing Industry & 18 & -1.5 & 0.0 & -0.3 \\
\hline Mining & 20 & -1.2 & 2.5 & 1.2 \\
\hline Vegetable Oil & 9 & 0.2 & 15.8 & 15.3 \\
\hline Wheat Milling & 40 & 2.0 & -3.1 & -2.2 \\
\hline Rice Milling IRRI & 8 & -1.5 & -1.4 & -1.4 \\
\hline Rice Milling Basmati & 16 & -0.2 & -2.4 & -2.0 \\
\hline Sugar & 48 & 2.3 & -2.9 & -1.9 \\
\hline Other Food & 60 & -1.9 & 2.0 & 1.1 \\
\hline Cotton Lint/Yarn & 49 & -3.1 & 0.0 & -0.6 \\
\hline Textiles & 121 & -2.4 & 0.3 & 0.1 \\
\hline Leather & 4 & -6.1 & 4.2 & 2.3 \\
\hline Wood Products & 22 & -1.2 & 2.6 & 1.3 \\
\hline Chemicals & 17 & -1.2 & 4.2 & 2.9 \\
\hline Cement/Bricks & 49 & 0.6 & -0.7 & -0.4 \\
\hline Petroleum Refining & 21 & -1.2 & 4.9 & 2.9 \\
\hline Other Manufacturing & 86 & -2.3 & 3.0 & 1.7 \\
\hline Energy & 115 & 0.2 & -0.4 & -0.2 \\
\hline Construction & 106 & 0.0 & 0.0 & 0.0 \\
\hline Commerce & 506 & 0.0 & 0.6 & 0.5 \\
\hline Transport & 401 & 0.6 & -1.9 & -1.1 \\
\hline Private Services & 426 & 0.5 & 0.0 & -0.2 \\
\hline Public Services & 285 & 0.6 & -0.5 & -0.3 \\
\hline
\end{tabular}

Sim-1: 50 percent increase in foreign savings, Sim-2: 10 percent increase in import price of petroleum, Sim-3: 10 percent increase in import price of industrial raw material 
Table-8: Quantity of Imports (\% Change from Base)

\begin{tabular}{lcccc}
\hline & BASE & Sim-1 & Sim-2 & Sim-3 \\
\hline Wheat Irrigated & 2.9 & 11.9 & -13.4 & 1.4 \\
Other Major Crop & 6.2 & 8.6 & -7.2 & 7.9 \\
Fruits/Vegetable & 17.2 & 11.3 & -64.0 & -57.2 \\
Cattle & 7.0 & 28.6 & -42.8 & -26.3 \\
Forestry & 2.9 & 3.9 & -10.3 & -1.6 \\
Fishery & 0.2 & 12.9 & -28.2 & -11.7 \\
Mining & 98.3 & -0.4 & 1.0 & 0.8 \\
Vegetable Oil & 32.6 & 13.1 & -68.5 & -62.8 \\
Wheat Non-Irrigated & 8.5 & 20.2 & -27.9 & -12.0 \\
Sugar & 3.4 & 22.5 & -31.4 & -14.4 \\
Other Food & 16.0 & 10.5 & -39.2 & -29.3 \\
Cotton Yarn/Lint & 7.3 & 0.2 & -13.4 & -2.3 \\
Textile & 18.2 & 11.2 & -51.8 & -42.4 \\
Leather & 1.7 & 20.3 & -57.0 & -47.4 \\
Wood & 6.3 & 4.1 & -11.3 & -3.0 \\
Chemical & 122.6 & 4.6 & -12.4 & -8.4 \\
Petroleum Refining & 104.6 & 3.8 & -10.1 & -5.9 \\
Other Manufacturing & 571.0 & 1.8 & -6.2 & -3.6 \\
Commerce & 2.7 & 14.9 & -27.9 & -12.7 \\
Private Services & 52.5 & 10.4 & -18.7 & -8.8 \\
\hline
\end{tabular}

Sim-1: 50 percent increase in foreign savings, Sim-2: 10 percent increase in import price of petroleum, Sim-3: 10 percent increase in import price of industrial raw material 
Table-9: Quantity of Exports (\% Change from Base)

\begin{tabular}{lcccc}
\hline & BASE & Sim-1 & Sim-2 & Sim-3 \\
\hline Wheat Irrigated & 4.9 & -8.6 & -16.3 & -14.3 \\
Other Major Crop & 3.8 & -8.4 & -17.2 & -16.2 \\
Fruits/Vegetable & 7.3 & -9.2 & -15.2 & -15.1 \\
Cattle & 0.6 & -21.8 & 9.2 & 1.2 \\
Poultry & 0.2 & -22.2 & 12.2 & 3.3 \\
Forestry & 3.1 & -5.2 & -11.7 & -8.3 \\
Fishery & 8.2 & -9.8 & 3.2 & 0.6 \\
Mining & 5.2 & -1.6 & -11.8 & -4.9 \\
Vegetable Oil & 0.2 & -9.6 & -3.7 & -5.5 \\
Wheat Milling & 3.6 & -11.0 & 0.9 & -1.1 \\
Rice Milling Irri & 10.4 & -7.9 & 0.5 & -1.3 \\
Rice Milling Basmati & 14.8 & -8.9 & 0.8 & -1.4 \\
Sugar & 0.3 & -12.4 & 5.9 & 1.8 \\
Other Food & 76.1 & -6.2 & 0.5 & -1.1 \\
Cotton Yarn / Lint & 62.8 & -4.8 & -4.4 & -4.1 \\
Textile & 217.9 & -7.2 & 0.6 & -0.5 \\
Leather & 13.6 & -16.0 & 7.3 & 2.5 \\
Wood & 0.4 & -5.5 & -5.9 & -3.0 \\
Chemical & 9.4 & -5.2 & -13.4 & -9.4 \\
Cement & 0.3 & -16.2 & 15.0 & 8.5 \\
Other Manufacturing & 111.7 & -4.3 & -8.9 & -5.3 \\
Commerce & 0.6 & -8.7 & 9.2 & 4.7 \\
Transport & 122.2 & -6.6 & 1.8 & 1.0 \\
Private Services & 0.3 & -8.5 & 6.8 & 3.7 \\
\hline
\end{tabular}

Sim-1: 50 percent increase in foreign savings, Sim-2: 10 percent increase in import price of petroleum, Sim-3: 10 percent increase in import price of industrial raw material 
Table-10: Household Income (\% Change from Base)

\begin{tabular}{lcccc}
\hline & BASE & Sim-1 & Sim-2 & Sim-3 \\
\hline Large Farmers_Sindh & 23 & -1.1 & 2.4 & 2.2 \\
Large Farmers_Punjab & 68 & -0.7 & 1.3 & 1.3 \\
Large Farmers_Other & 14 & -0.1 & -0.1 & 0.1 \\
Medium Farmers_Sindh & 48 & -0.6 & 2.0 & 1.9 \\
Medium Farmers_Punjab & 151 & -0.3 & 0.0 & 0.5 \\
Medium Farmers_Other & 39 & -0.7 & 1.5 & 1.4 \\
Small Farmers_Sindh & 61 & 1.1 & -1.1 & -0.2 \\
Small Farmers_Punjab & 323 & 0.5 & -1.1 & -0.2 \\
Small Farmers_Other & 129 & 1.2 & -2.6 & -1.4 \\
Small Farm & 47 & 1.0 & -0.8 & 0.0 \\
Renters_Landless_Sindh & & & & \\
Small Farm & 50 & 0.4 & -1.4 & -0.5 \\
Renters_Landless_Punjab & & & & \\
Small Farm & 19 & 1.0 & -1.4 & -0.5 \\
Renters_Landeless_Other & & & & \\
Rural agricultural & 24 & 1.7 & -3.7 & -2.2 \\
Workers_Landless_Sindh & & & & \\
Rural Agricultural & 72 & 1.4 & -4.0 & -2.4 \\
Workers_Landless_Punjab & & & & \\
Rural Agricultural & 12 & 3.0 & -4.5 & -2.5 \\
Workers_Landess_Other & & & -5.1 & -3.4 \\
Rural Non_Farm Non_Poor & 423 & 0.7 & -5.2 & -3.5 \\
Rural Non_Farm Poor & 143 & 1.0 & -4.2 & -3.0 \\
Urban Non_Poor & 1830 & 0.3 & -4.8 & -3.2 \\
Urban Poor & 194 & 0.4 & & \\
\hline & & & & \\
\hline
\end{tabular}

Sim-1: 50 percent increase in foreign savings, Sim-2: 10 percent increase in import price of petroleum, Sim-3: 10 percent increase in import price of industrial raw material 
Table-11: Household Consumption Expenditure (\% Change from Base)

\begin{tabular}{|c|c|c|c|c|}
\hline & BASE & Sim-1 & Sim-2 & Sim-3 \\
\hline Large Farmers_Sindh & 20 & 1.2 & 1.3 & 1.5 \\
\hline Large Farmers_Punjab & 59 & 1.6 & 0.2 & 0.7 \\
\hline Large Farmers_Other & 13 & 2.3 & -1.2 & -0.5 \\
\hline Medium Farmers_Sindh & 44 & 1.7 & 0.9 & 1.3 \\
\hline Medium Farmers_Punjab & 137 & 1.9 & -1.0 & -0.1 \\
\hline Medium Farmers_Other & 36 & 1.5 & 0.4 & 0.8 \\
\hline Small Farmers_Sindh & 55 & 3.4 & -2.2 & -0.8 \\
\hline Small Farmers_Punjab & 293 & 2.8 & -2.1 & -0.8 \\
\hline Small Farmers_Other & 117 & 3.5 & -3.6 & -2.0 \\
\hline $\begin{array}{l}\text { Small Farm } \\
\text { Renters_Landless_Sindh }\end{array}$ & 42 & 3.3 & -1.9 & -0.6 \\
\hline $\begin{array}{l}\text { Small Farm } \\
\text { Renters_Landless_Punjab }\end{array}$ & 46 & 2.7 & -2.4 & -1.1 \\
\hline $\begin{array}{l}\text { Small Farm } \\
\text { Renters_Landeless_Other }\end{array}$ & 17 & 3.3 & -2.4 & -1.1 \\
\hline $\begin{array}{l}\text { Rural Agricultural } \\
\text { Workers_Landless_Sindh }\end{array}$ & 22 & 4.0 & -4.8 & -2.8 \\
\hline $\begin{array}{l}\text { Rural Agricultural } \\
\text { Workers_Landless_Punjab }\end{array}$ & 65 & 3.7 & -5.0 & -3.0 \\
\hline $\begin{array}{l}\text { Rural Agricultural } \\
\text { Workers_Landess_Other }\end{array}$ & 11 & 5.4 & -5.5 & -3.1 \\
\hline Rural Non_Farm Non_Poor & 363 & 3.2 & -6.1 & -4.0 \\
\hline Rural Non_Farm Poor & 130 & 3.3 & -6.2 & -4.1 \\
\hline Urban Non_Poor & 1407 & 2.7 & -5.3 & -3.6 \\
\hline Urban Poor & 176 & 2.7 & -5.8 & -3.8 \\
\hline
\end{tabular}

Sim-1: 50 percent increase in foreign savings, Sim-2: 10 percent increase in import price of petroleum, Sim-3: 10 percent increase in import price of industrial raw material 
Table-12: Poverty and Inequality Results (\% Change from Base)

\begin{tabular}{lccc}
\hline & Sim-1** & Sim-2 & Sim-3 \\
\hline Overall Pakistan & & & \\
FGT (0)* & -3.083 & 4.054 & 3.426 \\
FGT (1) & -2.955 & 5.008 & 4.060 \\
FGT (2) & -2.794 & 4.597 & 3.695 \\
Punjab Province & & & \\
FGT (0) & -3.258 & 2.844 & 2.559 \\
FGT (1) & -1.484 & 2.613 & 2.232 \\
FGT (2) & -0.894 & 1.583 & 1.341 \\
Sindh Province & & & \\
FGT (0) & -2.843 & 8.250 & 6.345 \\
FGT (1) & -3.694 & 6.081 & 4.177 \\
FGT (2) & -2.908 & 4.541 & 3.061 \\
NWFP Province & & & \\
FGT (0) & -2.701 & 1.089 & 1.031 \\
FGT (1) & -1.214 & 2.045 & 1.752 \\
FGT (2) & -0.957 & 1.504 & 1.263 \\
Baluchistan Province & & & \\
FGT (0) & -0.687 & 0.558 & 0.558 \\
FGT (1) & -1.270 & 1.881 & 1.458 \\
FGT (2) & -0.512 & 0.863 & 0.674 \\
Gini & -0.322 & 0.382 & 0.158 \\
p90/p10*** & -1.005 & 0.502 & -0.100 \\
p90/p50 & -0.220 & 0.265 & 0.309 \\
p75/p25 & -0.228 & 0.913 & 0.639 \\
A(0.5)*** & -0.579 & 0.657 & 0.258 \\
A(1) & -0.570 & 0.539 & 0.164 \\
A(2) & -0.470 & -0.130 & -0.395 \\
\hline
\end{tabular}

*FGT (0): Headcount Ratio (proportion poor), FGT(1): average normalized poverty gap, FGT(2): average squared normalized poverty gap.

** Sim-1: 50 percent increase in foreign savings, Sim-2: 10 percent increase in import price of petroleum, Sim-3: 10 percent increase in import price of industrial raw material ***Percentile ratios

*****Atkinson measure 


\section{References}

Adams R.H. (1995). Sources of Income Inequality and Poverty in Rural Pakistan. Research Report 102, IFPRI, Washington D.C.

Ahmed, V., and O' Donoghue, C. (2010). Tariff Reduction in a Small Open Economy. Seoul Journal of Economics. 23(2).

Alatas, V., and Bourguignon, F. (2005). The Evolution of Income Distribution during Indonesia's Fast Growth, 1980-1996. In The Microeconomics of Income Distribution Dynamics in East Asia and Latin America. Bourguignon, François, Ferreira, F., and Lustig, N. (eds.) World Bank and Oxford University Press: New York.

Anderson, K., Dimaran, B., Francois, J., Herte1, T., and Hoekman, B. (2003). The Cost of Rich (and Poor) Country Protection to Developing Countries. Journal of African Economies, 10(3), 227257.

Anwar, T. (2005). Long-Term Changes in Income Distribution in Pakistan: Evidence Based on Consistent Series of Estimates. CRPRID Discussion Paper Series No. 3.

Aristovnik, A. (2008). Short-Term Determinants of Current Account Deficits. Eastern European Economics, 46(1), 24-42.

Baclajanschi, I., Bouton, L., Mori, H., Ostojic, D., Pushak, T., and Tiongson, E.R. (2007). Rising Energy Prices in Moldova. Problems of Economic Transition, 49(10), 5-40.

Ben Hammouda, H., and Osakwe, P.N. (2008). Global Trade Models and Economic Policy Analyses: Relevance, Risks And Repurcussions for Africa. Development Policy Review, 26(2), 151-170.

Bourguignon F., Robilliard, A-S., and Robinson, S. (2003). Representative versus Real Households in the Macro-Economic Modelling of Inequality. Document de Travail 2003-10, DIAL.

Bresser-Pereira, L.C., and Gala, P. (2008). Foreign Savings, Insufficiency of Demand, and Low Growth. Journal of Post Keynesian Economics, 30(3).

Bussolo, M., and Lay, J. (2003). Globalization and Poverty Changes in Colombia. OECD Development Center Working Paper No. 226. 
Coady, D.P., and Lee Harris, R. (2004). Evaluating Transfer Programmes within a General Equilibrium Framework. The Economic Journal, 114, 778-799.

Cockburn, J., Decaluwe, B., and Robichaud, V. (2008). Trade Liberalization and Poverty - Lessons from Asia and Africa. Chapter 12 in Cockburn, J., Decaluwe, B., and Robichaud, V. (eds.) Trade Liberalization and Poverty: A CGE Analysis of the 1990s Experience in Africa and Asia. Poverty and Economic Policy (PEP) Research Network.

Coe, D.T., Helpman, E., and Hoffmaister, A.W. (1997). North-South R \& D Spillovers. The Economic Journal, 107(440), 134-49.

Davies, J.B. (2004). Microsimulation, CGE and Macro Modelling for Transition and Developing Economies. UNU/WIDER Research Paper.

Dervis, K., De Melo, J., and Robinson, S. (1982). General Equilibrium Models for Development Policy. New York: Cambridge University Press.

Dorosh, P., Niazi, M.K., and Nazli, H. (2004). A Social Accounting Matrix for Pakistan, 2001-02: Methodology and Results. A Background Research Paper for the Pakistan Rural Factor Markets Study, World Bank, South Asia Rural Development Unit.

Go, D.S. (1991). External Shocks, Adjustment Policies, and Investment: Illustrations from a Forward-Looking CGE Model of the Philippines. WPS 737, World Bank.

Gunter, B.G., Cohen, M.J., and Lofgren, H. (2005). Analysing Macro-Poverty Linkages: An Overview. Development Policy Review, 23(3), 243-265.

Haq, R., and Bhatti, M.A. (2009). Estimating Poverty in Pakistan: The NonFood Consumption Share Approach. PIDE Research Report No. 183.

Hérault, N. (2006). Building and Linking a Microsimulation Model to a CGE Model for South Africa. South African Journal of Economics, 45 (1) $57-74$.

Husain, I. (2007). Choices for Financing Fiscal and External Deficits. Contributed Article by former Governor of State Bank of Pakistan in Blue Chip.

ILO (1996). Wage Workers in Agriculture: Conditions of Employment and Work. International Labour Office: Geneva. 
Ito, T., and Sato, K. (2008). Exchange Rate Changes and Inflation in PostCrises Asian Economies: Vector Autoregression Analysis of the Exchange Rate Pass-Through. Journal of Money, Credit and Banking, 40(7), 1407-38.

Kraev, E., and Akolgo, B. (2005). Assessing Modelling Approaches to the Distributional Effects of Macroeconomic Policy. Development Policy Review, 23(3), 299-312.

Labus, M. (1988). The Pakistan Economy: A CGE Approach to Price Liberalization Policy and Public Sector Losses. University of Belgrade (Unpublished).

Lofgren, H., R. Lee Harris, S. Robinson, M. Thomas, M. E1-Said, (2002). A Standard Computable General Equilibrium Model in GAMS, Microcomputers in Policy Research 5, International Food Policy Research Institute, Washington D.C. 2002.

McCarthy, D., and Taylor, L. (1980). Macro Food Policy Planning: A General Equilibrium Model for Pakistan. The Review of Economics and Statistics, 62(1), 107-121.

McCarthy, J. (2007). Pass-Through of Exchange Rates and Import Prices to Domestic Inflation in some Industrialized Economies. Eastern Economic Journal, 33(4).

Naqvi, F. (1998). Energy, Economy and Equity Interactions in a CGE Model for Paksitan. Ashgate Publishing Ltd, Gower House: England.

Orcutt, G.H. (1957). A New Type of Socio Economic System. Review of Economics and Statistics, 58, 773-797.

Pacheco-Lopez, P., and Thirlwall, A.P. (2007). Trade Liberalization and the Trade-Off between Growth and the Balance of Payments in Latin America. International Review of Applied Economics, 21(4), 469-490.

Reisen, H. and Soto, M. (2001). Which Types of Capital Inflows Foster Developing-Country Growth? International Finance, 4(1), 1-14.

Robilliard, A.S., Bourguignon, F., and Robinson, S. (2001). Crisis and Income Distribution: A Micro-Macro Model for Indonesia. Paper presented at the OECD Development Centre Conference, Paris, France. 
Robinson, S., and Moataz, E.S. (2000). GAMS Code for Estimating a Social Accounting Matrix (SAM) Using Cross Entropy Methods (CE). Discussion Paper 64, Trade and Macroeconomics Division, IFPRI.

Robinson, S., and Lofgren, H. (2005). Macro Models and Poverty Analysis: Theoretical Tensions and Empirical Practice. Development Policy Review, 23(3), 267-283.

Saeed, K.A. (2005). Economy of Pakistan. Lahore: Pakistan.

Savard, L. (2005). Poverty and Inequality Analysis within a CGE Framework: A Comparative Analysis of the Representative Agent and Microsimulation Approaches. Development Policy Review, 23(3), 313-331.

Schintke, J., Stäglin, R., and Weiß, J.P. (2000). Higher Prices for Oil, Natural Gas and Mineral Oil Products: the Potential Price Effects in Individual Sectors of German Industry. Economic Bulletin, 37(12).

Siddiqui, R., and Kemal, A.R. (2002). Remittances, Trade Liberalization and Poverty in Pakistan: The Role of Excluded Variables in Poverty Change Analysis, Exploring links between Globalization and Poverty in Pakistan. A Study Project Funded by DFID-UK, Pakistan Institute of Development Economics, PIDE.

Vos, R. (1998). Aid Flows and Dutch Disease in a General Equilibrium Framework for Pakistan. Journal of Policy Modelling, 20(1), 77-109.

Vos, R. and De Jong, N. (2003). Trade Liberalization and Poverty in Ecuador: a CGE Macro-Microsimulation Analysis. Economic Systems Research, 15(2).

Voyvoda, E. and Yeldan, E. (2005). Turkish Macroeconomics under the IMF Program: Strangulation of the Twin-Targets, Lopsided Growth and Persistent Fragilities. Paper Presented at the $9^{\text {th }}$ Congress of the Turkish Social Sciences Association, Ankara.

Warr, P. (2005). The Transmission of Import Prices to Domestic Prices: An Application to Indonesia. Forthcoming in Applied Economic Letters.

Yusuf, A.A., and Resosudarmo, B.P. (2008). Mitigating Distributional Impact of Fuel Pricing Reform: The Indonesian Experience. ASEAN Economic Bulletin, 25(1), 32-47.

Zaouali, S. (2007). Impact of Higher Oil Prices on the Chinese Economy. OPEC Review, 31(3), 191-214. 
Annex - A: Elasticities and Output Shares

\begin{tabular}{|c|c|c|c|c|c|}
\hline & $\begin{array}{c}\text { Armington } \\
\text { Elasticity }\end{array}$ & $\begin{array}{c}\text { CET } \\
\text { Elasticity }\end{array}$ & Prod_e* & $\begin{array}{c}\text { Share in } \\
\text { Value } \\
\text { Added }\end{array}$ & $\begin{array}{c}\text { Value } \\
\text { Added/ } \\
\text { Output** }\end{array}$ \\
\hline Wheat Irrigated & 4.0 & 4.0 & 0.75 & 1.9 & 51.6 \\
\hline Wheat Non-Irrigated & - & - & 0.75 & 0.1 & 53.0 \\
\hline Paddy IRRI & 4.0 & 4.0 & 0.75 & 0.3 & 59.9 \\
\hline Paddy Basmati & 4.0 & 4.0 & 0.75 & 0.5 & 59.6 \\
\hline Cotton & 4.0 & 4.0 & 0.75 & 1.4 & 61.8 \\
\hline Sugarcane & 4.0 & 4.0 & 0.75 & 1.0 & 60.5 \\
\hline Other Major Crops & 4.0 & 4.0 & 0.75 & 2.9 & 70.8 \\
\hline Fruits/Vegetables & 4.0 & 4.0 & 0.75 & 3.6 & 64.5 \\
\hline Livestock/Cattle/Dairy & 4.0 & 4.0 & 0.75 & 10.3 & 53.4 \\
\hline Poultry & 4.0 & 4.0 & 0.75 & 0.7 & 49.0 \\
\hline Forestry & 4.0 & 4.0 & 0.75 & 0.3 & 75.3 \\
\hline Fishing Industry & 4.0 & 4.0 & 0.75 & 0.5 & 51.0 \\
\hline Mining & 3.0 & 3.0 & 0.75 & 0.6 & 66.6 \\
\hline Vegetable Oil & 3.5 & 3.0 & 1.50 & 0.3 & 8.5 \\
\hline Wheat Milling & 3.5 & 3.0 & 1.50 & 1.2 & 21.3 \\
\hline Rice Milling IRRI & 3.5 & 3.0 & 1.50 & 0.2 & 27.6 \\
\hline Rice Milling Basmati & 3.5 & 3.0 & 1.50 & 0.5 & 27.3 \\
\hline Sugar & 3.5 & 3.0 & 1.50 & 1.4 & 31.5 \\
\hline Other Food & 3.2 & 3.0 & 1.50 & 1.8 & 36.1 \\
\hline Cotton Lint/Yarn & 3.2 & 3.0 & 1.50 & 1.5 & 21.4 \\
\hline Textiles & 3.5 & 3.0 & 1.50 & 3.6 & 22.3 \\
\hline Leather & 3.5 & 3.0 & 1.50 & 0.1 & 9.3 \\
\hline Wood Products & 3.5 & 3.0 & 0.50 & 0.7 & 34.5 \\
\hline Chemicals & 3.0 & 3.0 & 0.50 & 0.5 & 27.5 \\
\hline Cement/Bricks & 3.5 & 3.0 & 0.50 & 1.4 & 53.0 \\
\hline Petroleum Refining & 3.0 & 3.0 & 0.50 & 0.6 & 19.8 \\
\hline Other Manufacturing & 3.2 & 3.0 & 0.50 & 2.6 & 25.3 \\
\hline Energy & 3.0 & 3.0 & 0.50 & 3.4 & 60.2 \\
\hline Construction & 3.2 & 3.0 & 1.50 & 3.2 & 41.1 \\
\hline Commerce & 3.0 & 2.0 & 0.50 & 15.0 & 83.4 \\
\hline Transport & 3.2 & 2.0 & 1.25 & 11.9 & 54.2 \\
\hline Housing & 3.2 & 2.0 & 1.25 & 4.8 & 80.4 \\
\hline Private Services & 2.0 & 2.0 & 1.25 & 12.7 & 53.5 \\
\hline Public Services & 2.0 & 2.0 & 1.25 & 8.5 & 65.8 \\
\hline
\end{tabular}

*Prod_e: Elasticity of substitution between factors - bottom of technology nest.

Prod_e_2: Elasticity of substitution between agg. factor \& intermediate - top of tech nest $=0.6$

Elasac: output aggregation elasticity $=4$

Frisch $=-2$

**SAM values from Dorsoh et al. (2004). 


\section{Annex - B: CGE Model}

\section{Price Block}

1. Import Price $P M_{c}=\left(1+t m_{c}\right) \cdot E X R \cdot p w m_{c}+\sum_{c^{\prime} \in C T} P Q_{c^{\prime}} \cdot i c m_{c^{\prime} c}$

$$
c \in C M
$$

2. Export Price

$$
P E_{c}=\left(1-t e_{c}\right) \cdot E X R \cdot p w e_{c}-\sum_{c^{\prime} \in C T} P Q_{c^{\prime}} \text { ice }_{c^{\prime} c}
$$

$$
c \in C E
$$

3. Demand Price of Domestic Non-

$$
P D D_{c}=P D S_{c}+\sum_{c^{\prime} \in C T} P Q_{c^{\prime}} . i c d_{c^{\prime} c} \quad c \in C D
$$

Traded Goods

4.Absorption

$$
\begin{aligned}
& P Q_{c} \cdot\left(1-t q_{c}\right) \cdot Q Q_{c}=P D D_{c} \cdot Q D_{c}+P M_{c .} Q M_{c} \\
& c \in(C D \cup C M)
\end{aligned}
$$

5. Marketed Output Value

$$
P X_{c} \cdot Q X_{c}=P D S_{c} \cdot Q D_{c}+\left(P E_{c} \cdot Q E_{c}\right) \quad c \in C X
$$

6. Activity Price

$$
\begin{array}{ll}
P_{a}=\sum_{c \in C} P X A C_{a c} \cdot \theta_{a c} & a \in A \\
\text { PINTA }_{a}=\sum_{c \in C} P Q_{c} . i c a_{c a} & a \in A
\end{array}
$$

7. Aggregate Intermediate Input

Price

8. Activity Revenue And Costs

$P A_{a}\left(1-t a_{a}\right) \cdot Q A_{a}=P V A_{a} \cdot Q V A_{a}+P I N T A_{a} \cdot Q I N T A_{a}$

9. Consumer Price Index

$a \in A$

$$
\overline{C P I}=\sum_{c \in C} P Q_{c} \cdot c w t s_{c}
$$

10. Producer Price Index For Non-

$$
\overline{D P I}=\sum_{c \in C} P D S_{c} \cdot d w t s_{c}
$$

Traded Marketed

Output

\section{Production and Commodity Block}

11.

CES Technology:

$$
\begin{aligned}
& Q A_{a}=\alpha_{a}^{a} \cdot\left(\delta_{a}^{a} \cdot Q V A_{a}^{-\rho_{a}^{a}}+\left(1-\delta_{a}^{a}\right) \cdot Q I N T A_{a}^{-\rho_{a}^{a}}\right)^{-\frac{1}{\rho_{a}^{a}}} \\
& a \in A C E S \quad a \in A
\end{aligned}
$$

Activity Production

Function

12.

CES Technology: ValueAdded IntermediateInput Quantity Ratio

13.

$$
\frac{Q^{2} A_{a}}{\text { INTA }_{a}}=\left(\frac{P I N T A_{a}}{P V A_{a}} \cdot \frac{\delta_{a}^{a}}{1-\delta_{a}^{a}}\right)^{\frac{1}{1+\rho_{a}^{a}}} \quad a \in A C E S
$$

$$
Q V A_{a}=i v a_{a} \cdot Q A_{a} \quad a \in A L E O
$$

Leontief Technology:

Demand for Aggregate

Value-Added 
14.

Leontief Technology:

$$
\operatorname{QINTA}_{a}=\operatorname{int} a_{a} \cdot Q A_{a} \quad a \in A L E O
$$

Demand for Aggregate

Value-Added

15.

Value-Added and Factor

Demands

$Q V A_{a}=\alpha_{a}^{v a} \cdot\left(\sum_{f \in F} \delta_{f a}^{v a} \cdot Q F_{f a}^{-\rho_{a}^{v a}}\right)^{-\frac{1}{\rho_{a}^{v a}}} \quad a \in A$

16.

Factor Demand

$$
W_{f} \cdot \overline{W F D I S T}_{f a}=P V A_{a} \cdot\left(1-t v a_{a}\right) \cdot Q V A_{a} \cdot\left(\sum_{f \in F^{\prime}} \delta_{f a}^{v a} \cdot Q 1\right.
$$

$$
f \in F, a \in A
$$

17. Disaggregated

$\mathrm{QINT}_{c a}=i c a_{c a} \cdot \mathrm{QINTA}_{\alpha}$

$$
c \in C, a \in A
$$

Intermediate Input

Demand

18.

Commodity Production and Allocation

$$
Q X A C_{a c}+\sum_{h \in H} Q H A_{a c h}=\theta_{a c} \cdot Q A_{\alpha}
$$

$a \in A, a \in C X$

19. Output Aggregation

Function

$$
\begin{aligned}
& Q X_{c}=\alpha_{c}^{a c} \cdot\left(\sum_{a \in A} \delta_{a c}^{a c} \cdot Q X A C_{a c}^{-\rho_{c}^{a c}}\right)^{-\frac{1}{\rho_{c}^{a c}-1}} \\
& C \in C X
\end{aligned}
$$

20.

First-Order Condition for Output Aggregation Function

$P X A C_{a c}=P X_{c} \cdot Q X_{c}\left(\sum_{a \in A^{\prime}} \delta_{a c}^{a c} \cdot Q X A C_{a c}^{-\rho_{c}^{a c}}\right)^{-1} \cdot \delta_{a c}^{a c} \cdot Q X A$

$a \in A, c \in C X$

21.

Output Transformation

(CET) Function

$Q X_{c}=\alpha_{c}^{t} \cdot\left(\delta_{c}^{t} \cdot Q E_{c}^{\rho_{c}^{t}}+\left(1-\delta_{c}^{t}\right) \cdot Q D_{c}^{\rho_{c}^{t}}\right) \frac{1}{\rho_{c}^{t}}$

$c \in(C E \cap C D)$

22.

Export-Domestic Supply Ratio

$\frac{Q E_{c}}{Q D_{c}}=\left(\frac{P E_{c}}{P D S_{c}} \cdot \frac{1-\delta_{c}^{t}}{\delta_{c}^{t}}\right)^{\frac{1}{\rho_{c}^{t}-1}}$

$c \in(C E \cap C D)$

23.

Output Transformation

$Q X_{c}=Q D_{c}+Q E_{c}$ for Non-Exported

$c \in(C D \cap C E N) \cup(C E \cap C D N)$

\section{Commodities}

24.

Composite Supply

(Armington) Function

$Q Q_{c}=\alpha_{c}^{q} \cdot\left(\delta_{c}^{q} \cdot Q M_{c}^{-\rho_{c}^{q}}+\left(1-\delta_{c}^{q}\right) \cdot Q D_{c}^{-\rho_{c}^{q}}\right)^{-\frac{1}{\rho_{c}^{q}}}$

$c \in(C M \cap C D)$ 
25.

Import-Domestic

Demand Ratio

$\frac{Q M_{c}}{Q D_{c}}=\left(\frac{P D D_{c}}{P M_{c}} \cdot \frac{\delta_{c}^{q}}{1-\delta_{c}^{q}}\right)^{\frac{1}{1+\rho_{c}^{q}}}$

26.

Composite Supply for Non-Imported Outputs

$Q Q_{c}=Q D_{c}+Q M_{c}$ $c \in(C D \cap C M N) \cup(C M \cap C D N)$

and Non-Produced

Imports

27.

Demand for

$Q T_{c}=\sum_{c^{\prime} \in C^{\prime}}\left(i c m_{c c^{\prime}} \cdot Q M_{c^{\prime}}+i c e_{c c^{\prime}} \cdot Q E_{c^{\prime}}+i c d_{c c^{\prime}} \cdot Q D_{c^{\prime}}\right)$

Transactions Services

$c \in C T$

Institution Block

28.

Factor Income

$Y F_{f}=\sum_{a \in A} W F_{f} \cdot \overline{W F D I S T}_{f a} \cdot Q F_{f a} \quad f \in F$

29. Institutional

Factor Incomes

$Y I F_{i f}=\operatorname{shif}_{\text {if }} \cdot\left\lfloor\left(1-t f_{f}\right) . Y F_{f}-\right.$ trnsfr $\left._{\text {row }, f} \cdot E X R\right\rfloor$

30.

Income of Domestic,

Non-Government

$i \in I N S D, f \in F$

Institutions

31.
$Y I_{i}=\sum_{f \in F} Y I F_{i f}+\sum_{i^{\prime} \in I N S D N G^{\prime}} T R I I_{i i^{\prime}}+$ trnsfr $_{i, g o v} \cdot \overline{C P I}+$ trnsfr $_{i, r o}$ $i \in I N S D N G$

Intra-Institutional

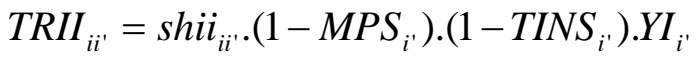

Transfers

32. Household

Consumption

Expenditure

$i \in I N S D N G, i^{\prime} \in I N S D N G^{\prime}$

33. Household

Consumption Demand for Marketed

Commodities

$E H_{h}=\left(1-\sum_{i \in I N S D N G} s h i i_{i h}\right) \cdot\left(1-M P S_{h}\right) \cdot\left(1-T I N S_{h}\right) \cdot Y I_{h}$

$h \in H$

34. Household

Consumption Demand

for Home

Commodities

$P Q_{c} \cdot Q H_{c h}=P Q_{c} \cdot \gamma_{c h}^{m}+\beta_{c h}^{m} \cdot\left(E H_{h}-\sum_{c^{\prime} \in C} P Q_{c^{\prime}} \cdot \gamma_{c^{\prime} h}^{m}-\sum_{a \in A} \sum_{c^{\prime} \in C}\right.$

$c \in C, h \in H$

35 . Investment

Demand

36. Government

Consumption Demand

$P X A C_{a c} \cdot Q H A_{a c h}=P X A C_{a c} \cdot \gamma_{a c h}^{h}+\beta_{a c h}^{h} \cdot\left(E H_{h}-\sum_{c^{\prime} \in C} P Q_{c} \cdot ;\right.$

$a \in A, c \in C, h \in H$

$Q I N V_{c}=\overline{q i n v_{c}} \cdot \overline{I A D J} \quad c \in C I N V$

$Q G_{c}=\overline{G A D J} \cdot \overline{q g_{c}} \quad c \in C$ 
37. Government

Revenue

$$
\begin{aligned}
& Y G=\sum_{i \in I N S D N G} T I N S_{i} \cdot Y I_{i}+\sum_{f \in F} t f_{f} \cdot Y F_{f}+\sum_{a \in A} t v a_{a} \cdot P V A_{a} \cdot Q \\
& +\sum_{a \in A} t a_{a} \cdot P A_{a} \cdot Q A_{a}+\sum_{c \in C M} t m_{c} \cdot p w m_{c} \cdot Q M_{c} \cdot E X R+\sum_{c \in C E} t e_{c} \\
& +\sum_{c \in C} t q_{c} \cdot P Q_{c} \cdot Q Q_{c}+\sum_{f \in F} Y I F_{g o v, f}+t r n s f r_{g o v, r o w} \cdot E X R \\
& E G=\sum_{c \in C} P Q_{c} \cdot Q G_{c}+\sum_{i \in I N S D N G} t r n s f r_{i, g o v} \cdot \overline{C P I}
\end{aligned}
$$

38. Government

Expenditures

\section{System Constraint Block}

39.

Factor Markets

$$
\sum_{a \in A} Q F_{f a}=\overline{Q F S}_{f} \quad f \in F
$$

40. Composite

Commodity Markets

$$
Q Q_{c}=\sum_{a \in A} Q I N T_{c a}+\sum_{h \in H} Q H_{c h}+q g_{c}+Q I N V_{c}+q d s t_{1}
$$

$$
c \in C
$$

41.

Current Account

$$
\sum_{c \in C M} p w m_{c} \cdot Q M_{c}+\sum_{f \in F} t_{r n s f r} r_{r o w, f}=\sum_{c \in C} p w e_{c} \cdot Q E_{c}+\sum_{i=I \Lambda}
$$

Balance for RoW (in foreign currency) 42. Government

Balance

43.

Direct Institutional

Tax Rates

44. Institutiona1

Savings Rates

45.

Savings Investment

Balance

46.

Total Absorption

47.

Ratio of Investment to Absorption

48.

Ratio of Government Consumption to Absorption
$Y G=E G+G S A V$

TINS $_{i}=\overline{\text { tins }_{i}} \cdot\left(1+\overline{\text { TINSADJ }}\right.$.tins $\left.01_{i}\right)+\overline{\text { DTINS }}$. tins 01 $i \in I N S D N G$

MPS $_{i}=\overline{m p s_{i}} \cdot\left(1+\overline{M P S A D J} \cdot m p s 01_{i}\right)+$ DMPS.mps0 $i \in I N S D N G$

$\sum_{i \in I N S D N G} M P S_{i} \cdot\left(1-\right.$ TINS $\left._{i}\right) \cdot Y I_{i}+G S A V+E X R \cdot \overline{F S A V}=\sum_{c \in C} P($

$T A B S=\sum_{h \in H} \sum_{c \in C} P Q_{c} \cdot Q H_{c h}+\sum_{a \in A} \sum_{c \in C} \sum_{h \in H} P X A C_{a c} \cdot Q H A_{a}$ $+\sum_{c \in C} P Q_{c} \cdot Q I N V_{c}+\sum_{c \in C} P Q_{c} \cdot q d s t_{c}$

INVSHR..TABS $=\sum_{c \in C} P Q_{c} \cdot Q I N V_{c}+\sum_{c \in C} P Q_{c} \cdot q d s t_{c}$

GOVSHR.TABS $=\sum_{c \in C} P Q_{c} \cdot Q G_{c}$ 


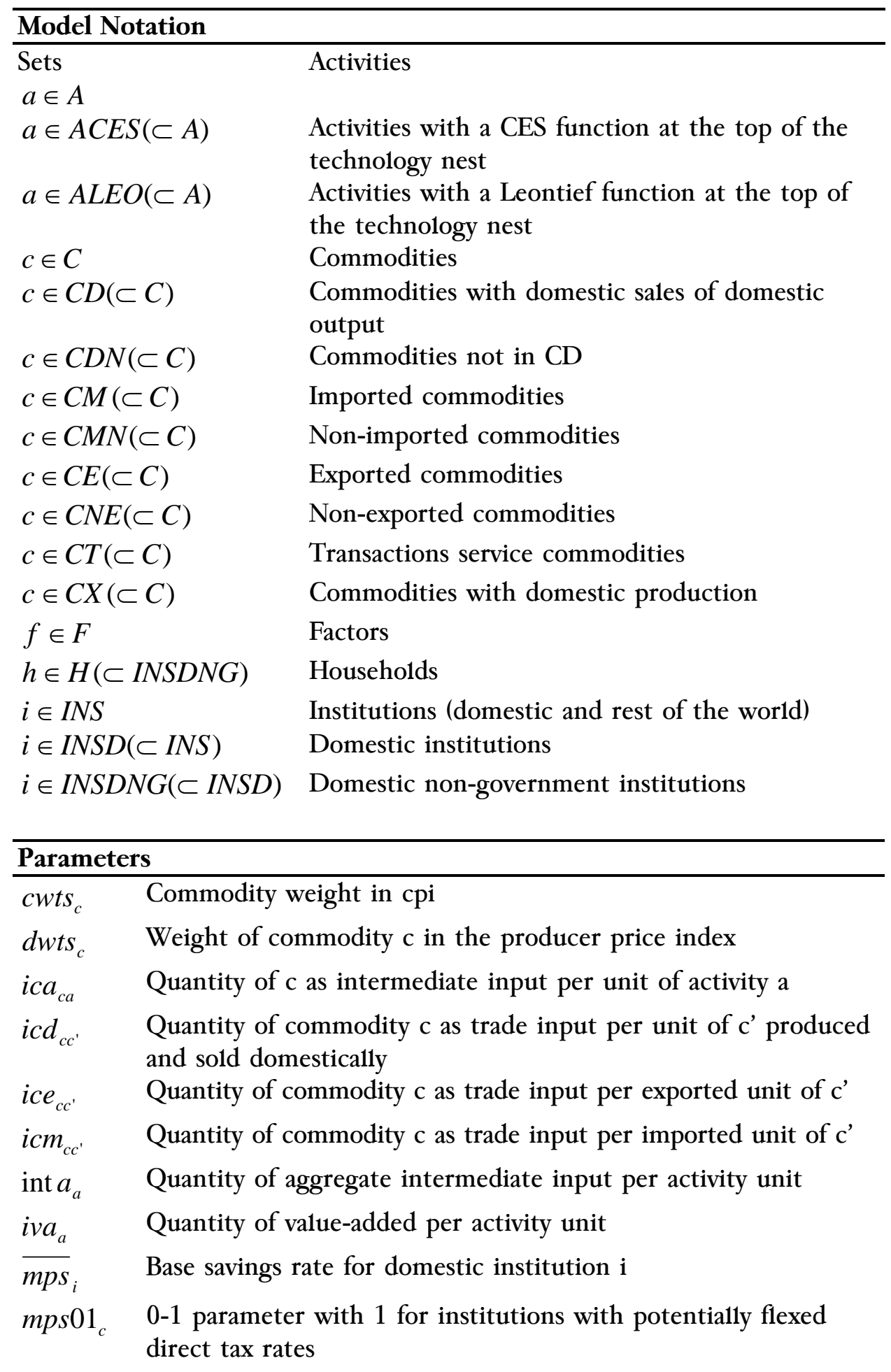


pwe $\quad$ Export price (foreign currency)

$\mathrm{pmw}_{\mathrm{c}} \quad$ Import price (foreign currency)

qdst $_{c} \quad$ Quantity of stock change

$\overline{q g}_{c} \quad$ Base-year quantity of government demand

$\overline{\operatorname{qinv}}_{c} \quad$ Base-year quantity of private investment demand

shif $_{\text {if }} \quad$ Share of domestic institution $\mathrm{i}$ in income of factor $\mathrm{f}$

shif $_{i i} \quad$ Share of net income of $\mathrm{i}^{\prime}$ to $\mathrm{i}$ ( $i^{\prime} \in I N S D N G^{\prime} ; i \in I N S D N G$ )

$t \alpha_{\alpha} \quad$ Tax rate for activity a

te $e_{c} \quad$ Export tax rate

$t f_{f} \quad$ Direct tax rate for factor $\mathrm{f}$

$\overline{\text { tins }_{i}} \quad$ Exogenous direct tax rate for factor $\mathrm{f}$

tins $01_{i} \quad 0-1$ parameter with 1 for institutions with potentially flexed direct tax rates

$\mathrm{tm}_{c} \quad$ Import tariff rate

$t q_{c} \quad$ Sales tax rate

trnsfr $r_{\text {if }} \quad$ Transfer from factor $\mathrm{f}$ to institution $\mathrm{i}$

tva $a_{a} \quad$ Rate of value added tax for activity a

ty $y_{h} \quad$ Rate of household income tax

$\alpha_{a}^{a} \quad$ Efficiency parameter in the CES activity function

$\alpha_{a}^{v a} \quad$ Efficiency parameter in the CES value-added function

$\alpha_{a}^{a c} \quad$ Shift parameter for domestic commodity aggregation function

$\alpha_{c}^{q} \quad$ Armington function shift parameter

$\alpha_{c}^{t} \quad$ CET function shift parameter

$\beta_{\text {ach }}^{h} \quad$ Marginal share of consumption spending on home commodity

$\beta_{c h}^{m} \quad$ Marginal share of consumption spending on marketed commodity c for household $h$

$\delta_{a}^{a} \quad$ CES activity function share parameter

$\delta_{a c}^{a c} \quad$ Share parameter for domestic commodity aggregation function

$\delta_{c}^{q} \quad$ Share parameter for composite supply (Armington function)

$\delta_{c}^{t} \quad$ Share parameter for output transformation (CET) function

$\delta_{v a}^{f a} \quad$ CES value added function share parameter for factor $\mathrm{f}$ in activity a 
$\gamma_{c h}^{m} \quad$ Subsistence consumption of marketed commodity c for household $\mathrm{h}$

$\gamma_{a c h}^{h} \quad$ Subsistence consumption of home commodity c from activity a for household $h$

$\theta_{a c} \quad$ Yield of commodity c per unit of activity a

$p_{a}^{a} \quad$ CES production function exponent

$p_{a}^{v a} \quad$ CES value added function exponent

$p_{c}^{a c} \quad$ Domestic commodity aggregation function exponent

$p_{c}^{q} \quad$ Armington function exponent

$p_{c}^{t} \quad$ CET function exponent

\section{Exogenous}

Variables

\begin{tabular}{|c|c|}
\hline$\overline{C P I}$ & Consumer price index \\
\hline$\overline{D T I N S}$ & $\begin{array}{l}\text { Change in domestic institution tax share ( }=0 \text { for base; } \\
\text { exogenous variable) }\end{array}$ \\
\hline$\overline{F S A V}$ & Foreign savings \\
\hline$\overline{G A D J}$ & Government consumption adjustment factor \\
\hline$\overline{I A D J}$ & Investment adjustment factor \\
\hline$\overline{M P S A D J}$ & Savings rate scaling factor ( $=0$ for base) \\
\hline$\overline{Q F S_{f}}$ & Quantity supplied of factor \\
\hline$\overline{T I N S A D J}$ & Direct tax scaling factor ( $=0$ for base; exogenous variable) \\
\hline$\overline{W F D I S T}_{f a}$ & Wage distortion factor for factor $\mathrm{f}$ in activity a \\
\hline
\end{tabular}

\section{Endogenous}

Variables

DMPS Change in domestic institution savings rates $(=0$ for base;
exogenous variable)

DPI Producer price index for domestically marketed output

EG Government expenditures

$\mathrm{EH}_{h} \quad$ Consumption spending for household

EXR Exchange rate (domestic currency per unit of foreign currency)

GOVSHR Government consumption share in nominal absorption

GSAV Government savings

INVSHR Investment share in nominal absorption

$M_{i} \quad$ Marginal propensity to save for domestic non-government institution (exogenous variable) 
$P A_{a} \quad$ Activity price (unit gross revenue)

$P D D_{c} \quad$ Demand price of quantity produced and sold domestically

$P D S_{c} \quad$ Supply price for commodity produced and sold domestically

$P E_{c} \quad$ Export price (domestic currency)

PINTA $_{a} \quad$ Aggregate intermediate input price for activity a

$P M_{c} \quad$ Import price (domestic currency)

$P Q_{c} \quad$ Composite commodity price

$P V A_{a} \quad$ Value-added price (factor income per unit of activity)

$P X_{c} \quad$ Producer price

$P X A C_{a c} \quad$ Producer price of commodity c for activity a

$Q A_{a} \quad$ Activity level

$Q D_{c} \quad$ Quantity of domestic output sold domestically

$Q E_{c} \quad$ Quantity of exports

$Q F_{f a} \quad$ Quantity demanded of factor $\mathrm{f}$ by activity a

$Q G_{c} \quad$ Government consumption demand for commodity

$\mathrm{QH}_{c h} \quad$ Quantity consumed of commodity c by household $\mathrm{h}$

$\mathrm{QHA}_{\text {ach }} \quad$ Quantity of household home consumption of commodity c from activity a for household $h$

QINTA $_{a} \quad$ Quantity of aggregated intermediate input

QINT $_{c a} \quad$ Quantity of commodity c as intermediate input to activity a

QINV $\quad$ Quantity of investment demand for commodity

QFS $_{f} \quad$ Supply of factor $\mathrm{f}$

$\mathrm{QH}_{c h} \quad$ Quantity of consumption of commodity c by household $\mathrm{h}$

QINT $_{c} \quad$ Quantity of intermediate use of commodity c by activity a

QINV $\quad$ Quantity of investment demand

$Q M_{c} \quad$ Quantity of imports

$Q Q_{c} \quad$ Quantity supplied to domestic commodity demanders (composite supply)

$Q T_{c} \quad$ Quantity of commodity demanded as trade input

QVA $_{a} \quad$ Quantity of (aggregate) value added

$Q X_{c} \quad$ Quantity of domestic output

QXAC $_{a c} \quad$ Quantity of marketed output of commodity c from activity a 
TABS Total nominal absorption

TINS $_{i} \quad$ Direct tax rate for institution i ( $\left.i \in I N S D N G\right)$

$T_{R I I} \quad$ Transfers from institution $\mathrm{i}^{\prime}$ to $\mathrm{i}$ (both in the set INSDNG)

$W F_{f} \quad$ Average wage (rental rate) of factor $\mathrm{f}$

$Y F_{f} \quad$ Transfer of income to household $\mathrm{h}$ from factor $\mathrm{f}$

YG Government revenue

$Y I_{i} \quad$ Income of domestic non-governmental institution

$Y_{\text {if }} \quad$ Income to domestic institution i from factor $\mathrm{f}$ 